\title{
Cement Resources, Agrominerals, Construction, Marble, Dimension and Decor Stone Resources, Gemstone and Jewelry Resources of Pakistan
}

\author{
Muhammad Sadiq Malkani \\ Geological Survey of Pakistan, Muzaffarabad, Azad Kashmir, Pakistan \\ Email:malkanims@yahoo.com
}

How to cite this paper: Malkani, M.S. (2020) Cement Resources, Agrominerals, Construction, Marble, Dimension and Decor Stone Resources, Gemstone and Jewelry Resources of Pakistan. Open Journal of Geology, 10, 900-942.

https://doi.org/10.4236/ojg.2020.108041

Received: May 3, 2020

Accepted: August 18, 2020

Published: August 21, 2020

Copyright ( 2020 by author(s) and Scientific Research Publishing Inc. This work is licensed under the Creative Commons Attribution International License (CC BY 4.0).

http://creativecommons.org/licenses/by/4.0/

\begin{abstract}
Large deposits of cement raw material and resources like limestone, gypsum and shales/clays found from the Koh Sulaiman area of South Punjab (Saraikistan) and Balochistan Provinces, Pakistan. The installation of cement industries especially in South Punjab/Saraikistan Province due to close occurrences of resources should develop the area and increase the export. The Koh Sulaiman regions of South Punjab (Saraikistan) have huge gypsum deposits which deserve for further exploitation. Pakistan is agricultural country and fertility of cultivated lands is vital. Fertilizer resources like phosphate deposits are moderate but the deposits of phosphate and potash bearing rocks are very vast and need their further explorations and exploitation in the Indus Basin. Pakistan has very large construction, dimension and decor stone deposits like limestone, marble, dolomite and igneous rocks like granite, dolerite, serpentine, etc. which needs further exploitation for the development of the areas and increase export. Pakistan is spending a lot of earnings for importing glass, glass wares, pottery, clay, etc. while Pakistan has these resources which needs exploitation of own resources. The best structures and geotectonic elements like the Northern and Western Indus Sutures and Karakoram Suture and Indus placers which are rich in gemstones and jewelry resources. To increase gems and jewelry export, these industries requires reduction in gemstones smuggling and encouragement for gem appraisal and jewelry industry at high level for value addition. In short, Pakistan is rich in natural resources but poor in development. Try should be made to develop and export the own mineral commodities like cement, gypsum, marble, gemstones and jewelry.
\end{abstract}

\section{Keywords}

Cement Resources, Agrominerals, Construction, Marble, Dimension and Decorstone Resources, Gems and Jewelry Resources, Export, Value 
Addition, Pakistan

\section{Introduction}

The development of all mineral resources of Pakistan is responsibility of federating units/provinces like Balochistan, North Punjab, South Punjab (Saraikistan/Saraiki Province), Sindh, Khyber Pakhtunkhwa), Capital Islamabad, Azad Kashmir and Gilgit Baltistan except the Radioactive minerals and Petroleum (oil and gas) which are under the jurisdiction of Federal government of Pakistan. Keeping in mind this, the every province should know the potential of their mineral resources, so this paper along with other papers on different provinces and basins is arranged for the easy approach and understanding of their individual mineral resources. So as well planning for the development and exploitation of their mineral resources should be implemented. At the time of independence in August 1947, Pakistan was generally perceived to be a country of low mineral potential, despite the knowledge regarding occurrences of large deposits of salt, gypsum, limestone, marble, etc. During 1950-1980, the geological community of Pakistan can be credited with several major achievements in economic geology such as discovery of major gas fields in Balochistan, uranium from foothills of Sulaiman Range in Punjab and southern KP, barite from Balochistan and KP, chromite and China clay in KP, famous emerald in KP, copper-gold and lead-zinc in Balochistan and KP. What has been found so far is much too small than what is expected to be discovered in not too distant future [1]. From independence to so far, many economic geologists presented revised and updated data and papers on mineral deposits of Pakistan. From the beginning of Pakistan, many geoscientists incorporated the new discoveries in the previous records and reported the review of mineral/minerals of Pakistan or part of it. The reference [2] presented a summary of known minerals of northwestern India (now Pakistan) with suggestions for development and use. The references [3] [4] reported economic minerals of Pakistan. The references [5] [6] [7] [8], recently [9] [10] presented a comprehensive report on mineral resources of Pakistan and reference [11] presented a report on mineral resources of Pakistan with basin and provinces wise which is easy for provinces to know their mineral resources. For easy approach, the mineral resources of each province were presented like Balochistan [12]-[25], Khyber Pakhtunkhwa [24]-[31], North and South Punjab [24] [25], [32] [33], Sindh [24] [25], [34] [35], Gilgit Baltistan [24] [25], [36] [37] [38] and Azad Kashmir [24] [25], [36] [37] [38]. Like this for the easy approach of mineral resources of each basin which was presented like Indus Basin subdivided into Kirthar Basin [14] [21] [22] [24] [25], Sulaiman Basin [14] [19] [20] [24] [25], Kohat Potwar Basin [24] [25] [26] [27] and Khyber-Hazara-upper Kashmir basin (part of Gondwana plate or gondwanalands, southern Earth) [24] [25] [26] [27], Kohistan-Ladakh (a part of Tethys) [24] [25] [26] [27], Hindu- 
kush-Karakoram (a part of Tethys and Laurasian or Asian Plate or northern Earth) [36] [37] [38], and Balochistan Basin [12]-[18], [23] [24] [25]. For easy approach of revised stratigraphic setup of each basin which was presented like Indus Basin which is subdivided into Kirthar Basin [14] [20] [21] [39] [40] [41] [42] [43], Sulaiman Basin [14] [17] [19] [20] [39] [40] [41] [42] [43], Kohat-Potwar-Kotli Basin [39]-[44], and Khyber-Hazara-Neelam basin (part of Gondwana plate or Gondwana lands, southern Earth) [39] [40] [44] [45], Kohistan-Ladakh (a part of Tethys) [39] [40] [44], Hindukush-Karakoram (a part of Tethys and Laurasian or Asian Plate or northern Earth) [39] [40] [44] and Balochistan Basin including fore arc (Makran-Siahan), arc (Chagai magmatic arc) and back arc (Pishin-Kaker-Khorasan) sub basins (part of PaleoTethys) [14] [17] [18] [23] [39] [40] [41] [46]. Recently many discoveries of gypsum and cement resources [14] [19] [20] [21] [22] [27] [28] [30] [32]-[37] [47] [48], fluorite [14] [15] [20] [21] [22], [49]-[54], celestite [14] [15] [19] [20] [21] [22] [53] [54] [55], coal [56]-[68], clay and ceramic [69], barite [70] [71], gold-silver associated with antimony [14] [15] [17], K-Pg boundary minerals [72], construction materials, marble and other commodities [73]-[79] are made.

The rise and fall of every country, provinces and nation partially depends on the mineral resources and their usage. This paper will add insights on Cement raw materials/Resources, Agrominerals, Construction, Marble, Dimension and Decor Stone Resources, Gemstone and Jewelry Resources of Pakistan.

\section{Materials and Methods}

The materials belong to compiled data from previous work especially mentioned in references and also new field data collected by present author during numerous field seasons regarding the potential of cement raw materials/resources, agrominerals, marble, construction, dimension and décor stones (Figure 1) (Figure 2), gemstone and jewelry resources of Pakistan (Figure 3). The methods applied here are many disciplines of purely geological description.

\section{Results and Discussion}

The potential of cement raw materials, agrominerals, marble, construction, dimension and décor stones (Figure 1) (Figure 2), gemstone and jewelry resources of Pakistan (Figure 3) are being presented here for quick and easy understanding.

\section{Cement Raw Materials/Resources from Pakistan}

Cement raw materials includes limestone $75 \%$ and clays/shale $25 \%$ for clinker preparation and further it needs gypsum 5\% as retarder. Cement Industry raw materials are huge in Pakistan (Figure 1) which requires more installation of cement industries especially in South Punjab (Saraikistan) and Balochistan Provinces. A lot of cement industries need to be installed in the Rajan Pur and D. G. Khan districts of South Punjab due to close occurrence of huge raw mate- 
rials like limestone, gypsum and shale which will be provided by belts. Pakistan has the lowest per capita consumption of cement. Further Pakistan is paying several hundred million rupees every year for calcium chemicals. It is vital to take step for installing more cement, lime and calcium chemicals industries, so that the country will be self-sufficient and able to export these materials to earn foreign exchange. More than a dozen cement industries should be installed in the Rajan Pur, D. G. Khan, D. I. Khan, Dera Bugti, Harand, Zinda Pir, Rakhi Gaj, Barkhan, Kohlu, Loralai and Musa Khel districts due to close existence of its raw materials. The Daman areas of Sulaiman Range like Dera Ismail Khan, Dera Ghazi Khan and Rajan Pur districts have only one cement industry while these areas have largest deposits of cement resources like limestone (huge deposits), shale (huge deposits) and also large gypsum deposits. Further these areas are relatively close to Sea ports for export and also crossed by CPEC routes. The

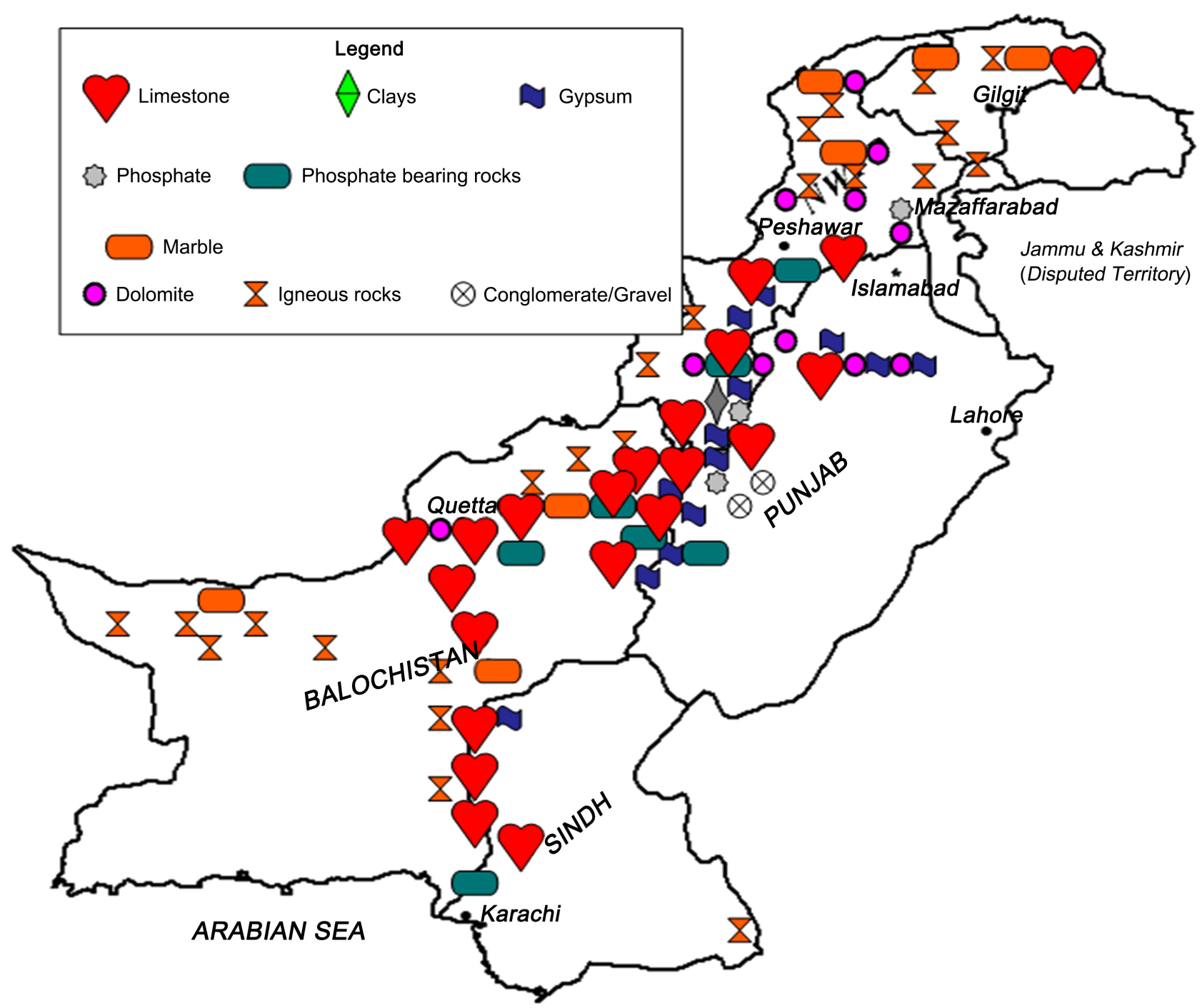

Figure 1. Map of Pakistan showing main cement raw resources (limestone, shale/clay, gypsum), agrominerals (rock phosphate, gypsum), marble, construction, dimension and décor stone resources (marble, dolomite, conglomerate and gravels, igneous rocks) of Pakistan. 


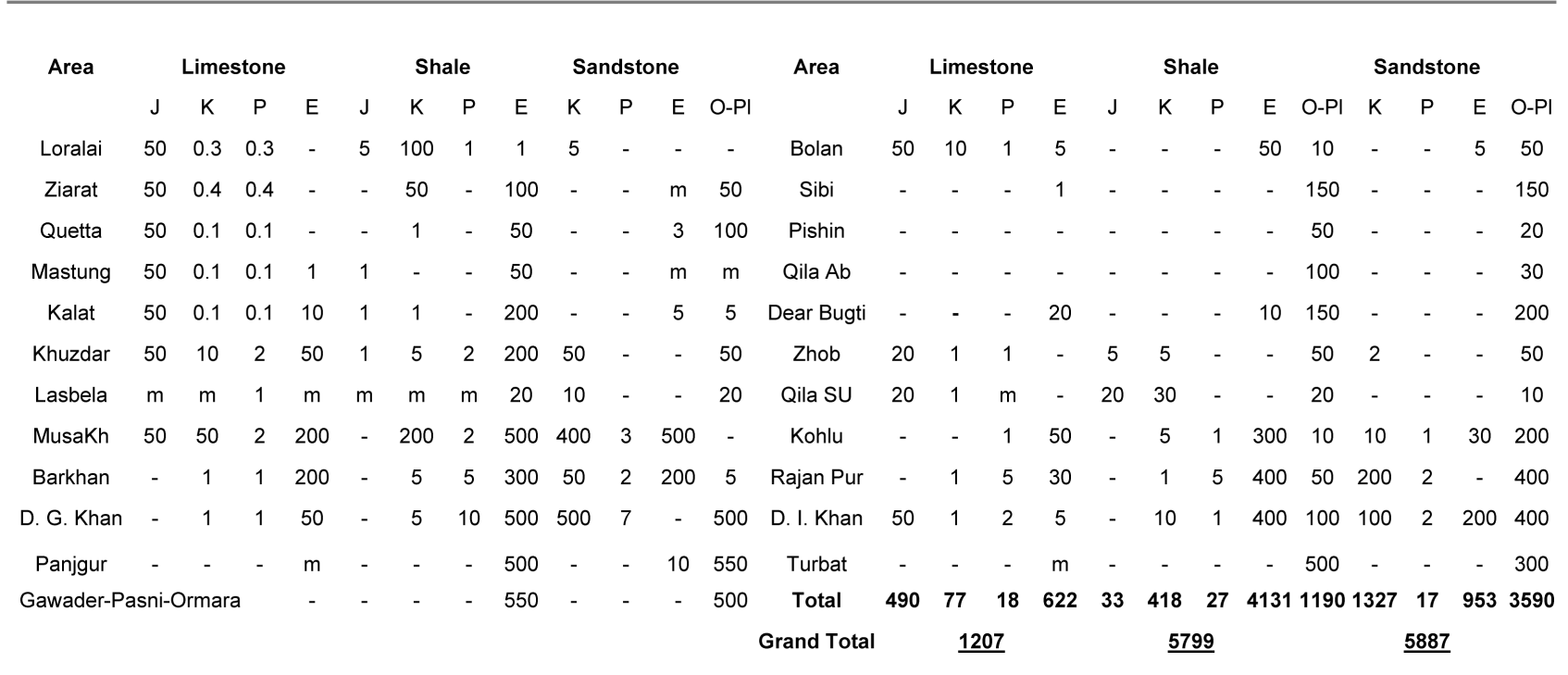

Figure 2. Limestone, Shale and Sandstone Resources (in billion tons from exposure to $200 \mathrm{~m}$ depth from ground surface) of Sulaiman and Kirthar foldbelts, Western Indus Suture and Balochistan Basin. Abbreviations; D. G. Khan-Dera Ghazi Khan, D. I. Khan-Dera Ismail Khan, E-Eocene, J-Jurassic, K-Cretaceous, m-minor, MusaKh-Musa Khel district of Balochistan Province, O-Oligocene, P-Paleocene, Pl-Pliocene, Qila SU-Qila Saif Ullah, Qila Ab-Qila Abdullah, Balochistan.

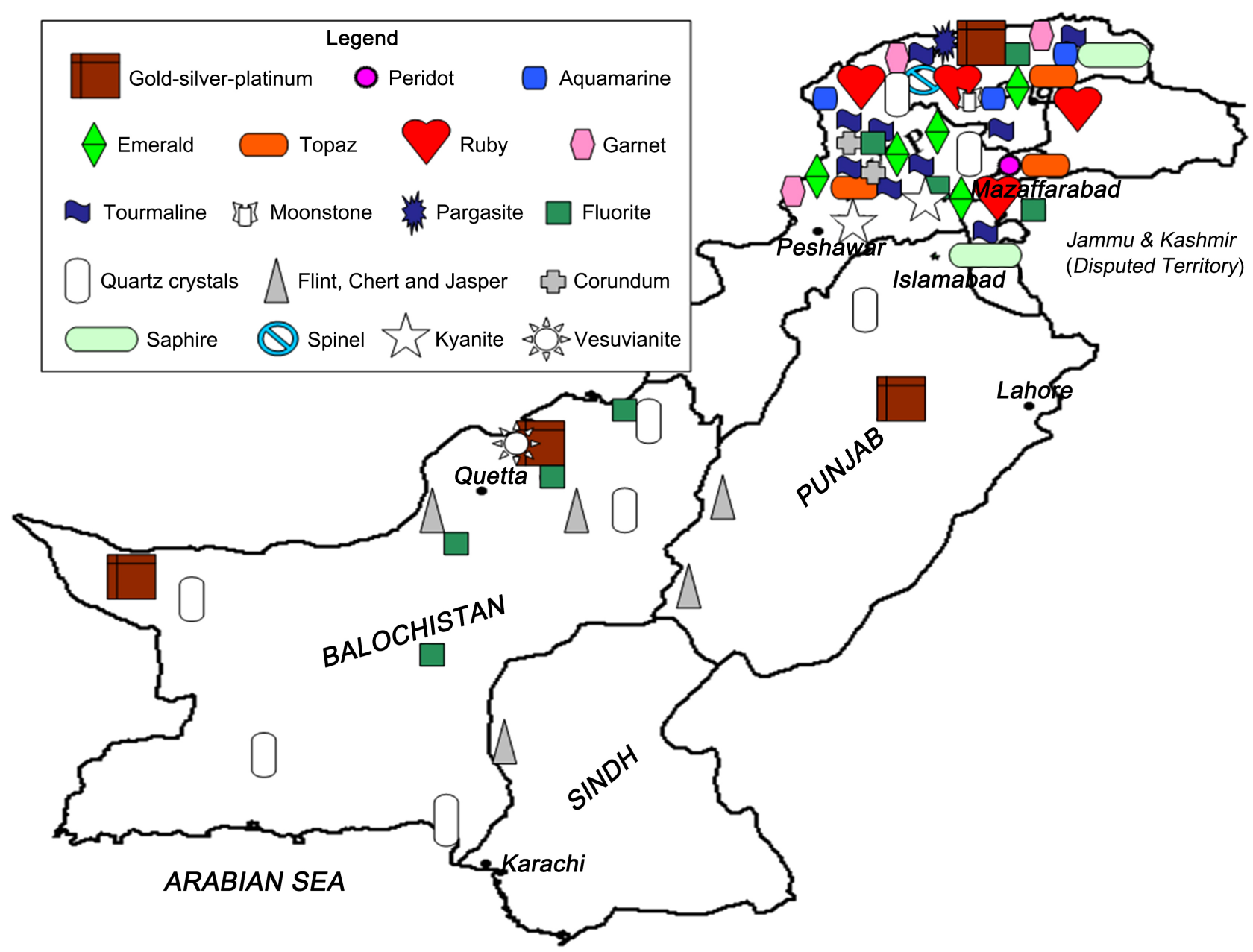

Figure 3. Map of Pakistan showing gemstone and jewelry resources of Balochistan, Sindh, North Punjab, South Punjab (Saraikistan), Khyber Pakhtunkhwa, Gilgit Baltistan and Azad Kashmir (Pakistan). 
eastern part of Balochistan (Sulaiman foldbelt) like Loralai, Barkhan, Musa Khel, Kohlu and Dera Bugti districts hosts more than 14 billion tons of gypsum but not producing or using own gypsum. So there is an urgent to exploit and export these huge gypsum deposits to increase the value additions. Further the areas of South Punjab (Rajan Pur and D. G. Khan districts of Saraiki Province), eastern Balochistan and D. I. Khan are located in the centre of Pakistan, cement and gypsum can be transported easily every where there is a demand and also for export. Further this area lies in the CPEC routes.

Limestone: Limestone is extensively used as crushed stone for concrete aggregates, road metal and rail road ballasts. It is the basic raw material for cement. Limestone is also used in steel mills as fluxing agent, soil conditioner, as a source of lime, chemical raw material and as dimension stone. It is also used for building, statuary, monumental and ornamental purposes. It can be used for making animal feed, water treatment and coal dust mines with relaxed specifications [80] [81]. The inexhaustible reserves of limestone (Figure 1) are found in Pakis$\tan [82]$. At some places it occurs near railway track for easy transportation. Present research show huge deposits of easily mineable (200 m depth to exposed surface) limestone of Sulaiman, Kirthar and Balochistan basins which are being estimated as round about 1207 bt with breakup as Jurassic 490 bt, Cretaceous 77 bt and Paleocene 18 bt, and Eocene 622 bt (Figure 2). The rocks generally contain $50 \%$ calcium oxide, less than $5 \%$ silica and less than $1 \%$ iron oxide making suitable for cement. A small fraction of resources are being used by cement industries in Pakistan. The limestone resources of South Punjab are being presented here.

Clays/Shale: Vast resources of shale are found in Pakistan (Figure 2) like Jurassic Spingwar, Cretaceous Sembar, Goru, Mughalkot and Vitakri formations, Paleocene Rakhi Gaj, Eocene Shaheed Ghat, Toi, Kingri, Drug, Baska, Domanda and Drazinda formations, Oligocene Vihowa and Chaudhwan formations, etc, along with many formations in Kohat and Potwar and also in Kirthar basins. Vast and huge deposits of easily mineable (200 m depth to exposed surface) shale/clays of Sulaiman, Kirthar and Balochistan basins are being estimated as round about 5799 bt with breakup as Jurassic 33 bt, Cretaceous 418 bt, Paleocene 27 bt, Eocene 4131 bt and Oligocene-Pliocene 1190 bt (Figure 2). Vast clay/shale ceramic resources of South Punjab are being presented as following.

Huge Gypsum Deposits: Gypsum is $\mathrm{CaSO}_{4} \cdot 24 \mathrm{H}_{2} \mathrm{O}$ and anhydrite is $\mathrm{CaSO}_{4}$. Alabaster is fine grained and compact snow white to light smoky white with low hardness (1.5 - 2) and low specific gravity (2.2). Gypsum is used as retarder in cement, as a fertilizer, as filler in various materials such as paper, crayons, paints, rubber, etc and in the manufacture of plaster of Paris for which purpose the mineral is heated to expel some of its water of crystallization and then ground up. Calcined gypsum is extensively employed in the building trade for the production of various types of plasters, sheets, and boards and for stucco work; it is also used as polishing beds, in the manufacture of plate glass, and as an adulte- 
rant of foods. Very large deposits of gypsum are found in Pakistan (Figure 1). Salt Range contains at least $137 \mathrm{mt}$ of gypsum [83]. Gypsum and anhydrite separate deposits are unknown. The reference [84] reported $10.4 \mathrm{mt}$ gypsum in three beds ranging in thickness from 0.33 to $0.93 \mathrm{~m}$ occurs in Miocene Gaj shales near Johi and K. N. Shah, Dadu district. The reference [12] reported some gypsum from Chagai (Gawalishtap gypsum in red shale of Washap formation) and Lasbela districts. Very large reserves of Jatta gypsum (4.7 bt) have been reported from Kohat region. Gypsum beds are $15-60 \mathrm{~m}$ thick and extend in a 55 $\mathrm{km}$ long belt. Main deposits occur at Braghdi, Shiwakki, Jatta, Nashpa-Chanda, Mami Khel, Manda Daud Shah, Lachi, Bahadur Khel, Karak, Banda Spina-Dhand, Idal Khel and Malgin [8] [85]. The Saiduwali Khisor gypsum deposits occur $3 \mathrm{~km} \mathrm{NW}$ of Saiduwali (D. I. Khan district) as alternating beds of dolomite and gypsum with $150 \mathrm{~m}$ thickness [3]. These Cambrian Khisor Formation gypsum beds dipping NW are found on the base of Khisor thrust fault near the general ground surface and seems feasible for cement industries. The present author Malkani discovered huge gypsum deposits from South Punjab (Saraikistan) and eastern Balochistan provinces geologically located in Sulaiman basin (middle Indus basin) of Pakistan [14] [19] [47].

The quality of Sulaiman gypsum is good as impurities are less than $2 \%$. There are one bed $(0.3 \mathrm{~m}-6 \mathrm{~m})$ of gypsum in Domanda Formation of Kahan group in only southern Sulaiman foldbelt and 4 to 15 beds of gypsum in Baska Formation of Chamalang group with cumulative thickness of $5 \mathrm{~m}$ to $25 \mathrm{~m}$ in both northern and southern Sulaiman foldbelt. Main environments of gypsum beds show platform type supratidal Sabkha paleo environments. The reference [14] reported 26 billion tons $(1 \mathrm{bt}=1000 \mathrm{mt}$ ) and [9] reported 28.5 billion tons of estimated reserves (measured, indicated, inferred and hypothetical), which are the first largest deposit in Pakistan. The breakup of total gypsum reserves includes $14.5 \mathrm{bt}$ in Balochistan Province (Barkhan 4.25 bt, Kohlu 5.5 bt, Sibi 1 bt, Dera Bugti 1.75 bt, Musa Khel 2 bt); 11 bt in Punjab (Rajan Pur 2 bt and D. G. Khan 9 bt); and 3.1 bt in KP (D. I. Khan and South Waziristan). The Balochistan Province with detail as Barkhan District includes Lakha Kach or Rakhni 1 bt, Kodi More-Nodo-Ishani-Gadumra 2 bt, Khurcha 0.25 bt, Anokai-Bahlol 0.5 bt and Bala Dhaka-Karher Buzdar 0.5 bt; Kohlu District includes Nisau-Safed 3 bt, Kahan-Khatan 1 bt, Mawand 1 bt, Lunda-Bahney Wali 0.25 bt and Janthali 0.25 bt; Dera Bugti includes Sham-Kulchas, Phailawagh-Jiandari, and Pirkoh 1.75 bt, Sibi district includes Spintangi $1 \mathrm{bt}$; and Musa Khel district includes Drug-Toi Nala-Zamaray 2 bt, Kingri $1 \mathrm{mt}$ and Chamoz Khan Mohd Kot $1 \mathrm{mt}$; Punjab province with detail as Rajan Pur district 2 bt and D. G. Khan district 9 bt; KPK province with detail as D. I. Khan district 3 bt and South Waziristan 0.1 bt. The reference [47] reported $588.4 \mathrm{mt}$ of easily minable reserves upto $50 \mathrm{~m}$ depth, [19] reported $675 \mathrm{mt}$ while the [9] reported $764 \mathrm{mt}$. Easily minable (upto $50 \mathrm{~m}$ depth) resources of gypsum are $451 \mathrm{mt}$ in Balochistan (Barkhan $121.3 \mathrm{mt}$, Kohlu 228.7 mt, Musa Khel $57 \mathrm{mt}$, Sibi $16 \mathrm{mt}$ and Dera Bugti $28 \mathrm{mt}$ ), $231 \mathrm{mt}$ in Punjab (Ra- 
jan Pur $33 \mathrm{mt}$ and D. G. Khan $198 \mathrm{mt}$ ), $82 \mathrm{mt}$ in KPK province (D. I. Khan $77 \mathrm{mt}$ and Waziristan $5 \mathrm{mt}$ ). Lakha Kach (Rakhni; Barkhan) gypsum deposits show $49.5 \mathrm{mt}$ easily minable reserves, located very close to the metalled road near Rakhni town, which is connected with D. G. Khan. Chemical analyses show that $\mathrm{CaO}$ content varies from $29.44 \%$ to $33.65 \%, \mathrm{SO}_{3}$ from $44.65 \%$ to $47.78 \%$, and $\mathrm{H}_{2} \mathrm{O}$ from $16.30 \%$ to $18.99 \%$. Kodi More-Nodo (Barkhan) gypsum deposits show $8.2 \mathrm{mt}$, located $20 \mathrm{~km}$ west of Rakhni town, which is situated near the Loralai-D. $\mathrm{G}$. Khan metalled road. Chemical analyses show that $\mathrm{CaO}$ content varies from $30.84 \%$ to $32.25 \%, \mathrm{SO}_{3}$ from $45.68 \%$ to $46.46 \%$, and $\mathrm{H}_{2} \mathrm{O}$ from $16.33 \%$ to $19.38 \%$. Ishani (Barkhan) gypsum deposits show $15.4 \mathrm{mt}$, located $35 \mathrm{~km}$ southwest of Rakhni town situated on Loralai-D. G. Khan metalled road. The towns close to the deposits are Rakhni and Barkhan which are connected with D. G. Khan by a metalled road. Chemical analyses show that $\mathrm{CaO}$ content varies from $30.84 \%$ to $32.25 \%, \mathrm{SO}_{3}$ from $45.50 \%$ to $46.79 \%$, and $\mathrm{H}_{2} \mathrm{O}$ from $16.59 \%$ to $19.48 \%$. Khurcha (Barkhan) gypsum deposits show $8.2 \mathrm{mt}$, located $15 \mathrm{~km}$ southwest of Rakhni town situated on Loralai-D. G. Khan metalled road. Chemical analyses show that $\mathrm{CaO}$ content varies from $28.4 \%$ to $32.24 \%, \mathrm{SO}_{3}$ from $44.32 \%$ to $46.07 \%$, and $\mathrm{H}_{2} \mathrm{O}$ from $18.25 \%$ to $19.22 \%$. Gadumra-Chang Mari (Barkhan) gypsum deposits show $7 \mathrm{mt}$, and are accessible from Barkhan through dirt and shingle track. Barkhan is connected through D. G. Khan metalled road. Chemical analyses show that $\mathrm{CaO}$ content varies from $31.89 \%$ to $32.24 \%, \mathrm{SO}_{3}$ from $45.72 \%$ to $46.71 \%$, and $\mathrm{H}_{2} \mathrm{O}$ from $18.17 \%$ to $18.87 \%$. Bala Dhaka-Karher Buzdar (Barkhan) gypsum deposits show $22 \mathrm{mt}$, located on the Kohlu-Duki partially metalled road. Bala Dhaka is located $30 \mathrm{~km}$ north of Kohlu town. The area is accessible from Kohlu and Barkhan through dirt and shingle track. Karher is located $60 \mathrm{~km}$ from Barkhan through a dirt and shingle track. Chemical analyses show that $\mathrm{CaO}$ content varies from $30.84 \%$ to $32.25 \%, \mathrm{SO}_{3}$ from $45.96 \%$ to $47.33 \%$, and $\mathrm{H}_{2} \mathrm{O}$ from $18.45 \%$ to $19.66 \%$.

Anokai-Bahlol (Barkhan) gypsum deposits show $11 \mathrm{mt}$ and are located $90 \mathrm{~km}$ northwest of Barkhan town. The Bahlol gypsum deposit started from $4.5 \mathrm{~km}$ west of village of Bahlol and ended on the west of Bala Dhaka village. It has been previously reported as the Chamalang deposit [5]. Reserves are estimated at 7 million tons upto a depth of $30 \mathrm{~m}$ [82]. It is very close to the metalled road near Rakhni town, which is connected with D.G.Khan. Chemical analyses show that $\mathrm{CaO}$ content varies from $31.61 \%$ to $32.24 \%, \mathrm{SO}_{3}$ from $45.96 \%$ to $46.47 \%$, and $\mathrm{H}_{2} \mathrm{O}$ from $18.90 \%$ to $19.70 \%$. Baghao Tumni (Barkhan) gypsum deposit show very small deposits and are located north of Barkhan town, which is connected with D. G. Khan. Chemical analyses show that $\mathrm{CaO}$ content varies from $31.54 \%$ to $32.25 \%, \mathrm{SO}_{3}$ from $44.95 \%$ to $46.15 \%$, and $\mathrm{H}_{2} \mathrm{O}$ from $19.27 \%$ to $19.67 \%$. Spintangi (Sibi) gypsum deposits show $16 \mathrm{mt}$ [86] and are located $60 \mathrm{~km} \mathrm{NNW}$ of Sibi town and accessible through a railway line from Sibi to Harnai. Nisau (Vitakri)-Safed (Kohlu) gypsum deposits show $137.5 \mathrm{mt}$, located $35 \mathrm{~km}$ SSW of Barkhan town and is accessible through a shingle track from Barkhan. Barkhan 
is the district headquarters and is connected with D.G.Khan and Loralai by metalled road. D. G. Khan town has railway link with major cities of the country. Chemical analyses show that $\mathrm{CaO}$ content varies from $30.84 \%$ to $32.24 \%, \mathrm{SO}_{3}$ from $45.28 \%$ to $47.54 \%$, and $\mathrm{H}_{2} \mathrm{O}$ from $18.04 \%$ to $19.66 \%$. Janthali (Kohlu) gypsum deposits show $7.7 \mathrm{mt}$ and can be approached through Beakar, Philawagh and Pathar Nala area of Dera Bugti district and also assessable via Kahan. It is $60 \mathrm{~km}$ NNE from Dera Bugti and $130 \mathrm{~km}$ SSW from Rakhni, connected via shingle and mud tracks. These deposits are found south of Vitakri. Kahan-Khattan (Kohlu) gypsum deposits show $33 \mathrm{mt}$ and are accessible from Sibi and Dera Bugti towns. Kahan is $70 \mathrm{~km}$ NNW of Dera Bugti connected via shingle and mud fair weather track. Khattan is $60 \mathrm{~km} \mathrm{NE}$ from Sibi connected fair weather mud and shingle track. Kahan-Khattan gypsum deposits are found in the strike of Harnai, Spin Tangi, Dera Bugti and some Rajan Pur deposits forming southern Sulaiman gypsum belt. Chemical analyses show that $\mathrm{CaO}$ content varies from $31.54 \%$ to $32.24 \%, \mathrm{SO}_{3}$ from $46.02 \%$ to $46.50 \%$, and $\mathrm{H}_{2} \mathrm{O}$ from $18.60 \%$ to $19.24 \%$. Mawand (Kohlu) gypsum deposits show $41.2 \mathrm{mt}$ and are located $90 \mathrm{~km}$ NNE of Sibi town. Jeepable track leading upto Mawand is very rough. Gypsum has been reported in Sibi District near Khattan. Chemical analyses show that $\mathrm{CaO}$ content varies from $31.95 \%$ to $32.25 \%, \mathrm{SO}_{3}$ from $45.40 \%$ to $46.77 \%$, and $\mathrm{H}_{2} \mathrm{O}$ from $18.85 \%$ to $20.18 \%$. Bohri Kohlu gypsum deposits show $1.1 \mathrm{mt}$ and are located $20 \mathrm{~km}$ south of Kohlu town. The area is accessible from Kohlu through dirt and shingle track. Chemical analyses show that $\mathrm{CaO}$ content varies from $31.40 \%$ to $32.52 \%, \mathrm{SO}_{3}$ from $45.90 \%$ to $46.70 \%$, and $\mathrm{H}_{2} \mathrm{O}$ from $18.60 \%$ to $19.77 \%$. Lunda-Bahney Wali (Kohlu) gypsum deposits show $8.2 \mathrm{mt}$ and are located $35 \mathrm{~km}$ north of Kohlu town and $80 \mathrm{~km}$ northwest of Barkhan town. The area is connected with Kohlu and Barkhan through dirt and shingle track. Pirkoh (Dera Bugti) gypsum deposits show $0.4 \mathrm{mt}$ and are accessible from Dera Bugti towns. Dera Bugti town is connected with Kashmor via Sui, and Sibi via Lahri. Pirkoh deposits include only one bed of Domanda gypsum. The chemical analysis of Domanda gypsum represents $\mathrm{CaO} 31.38 \%, \mathrm{SO}_{3} 46.30 \%, \mathrm{SiO}_{2} \quad 0.32 \%, \mathrm{Al}_{2} \mathrm{O}_{3} 1.10 \%, \mathrm{H}_{2} \mathrm{O} 20.89 \%$, $\mathrm{Fe}_{2} \mathrm{O}_{3}$ and $\mathrm{MgO}$ are in traces.

Phailawagh-Giandari (Dera Bugti) gypsum deposits show $10 \mathrm{mt}$ and are accessible from Dera Bugti towns. Its gypsum deposits are found in the strike of Harnai-Spin Tangi, Khatan-Kahan areas deposits forming southern Sulaiman gypsum belt. Sham-Kulchas (Dera Bugti) gypsum deposits show $17.6 \mathrm{mt}$ and can be approached from Harrand/Jampur/Rajan Pur. These deposits are also accessible from Dera Bugti town. The chemical analysis of Baska Gypsum indicates $\mathrm{CaO} 31.65 \%$ to $32.06 \%, \mathrm{SO}_{3} 41.02 \%$ to $43.05 \%, \mathrm{Fe}_{2} \mathrm{O}_{3} 1.19$ to $1.59, \mathrm{MgO} 0.50$, insoluble $0.80 \%$ to $3.22 \%$, and $\mathrm{H}_{2} \mathrm{O} 20.24 \%$ to $21.16 \%$. Kingri (Musakhel) gypsum deposits show $1 \mathrm{mt}$ and are located very close to Kingri town on metalled road. Chemical analyses show that $\mathrm{CaO}$ content varies from $31.04 \%$ to $32.53 \%$, $\mathrm{SO}_{3}$ from $41.43 \%$ to $47.09 \%$, and $\mathrm{H}_{2} \mathrm{O}$ from $17.94 \%$ to $19.88 \%$. Chamoz-Khan Mohd Kot (Musakhel) gypsum deposits show $1 \mathrm{mt}$ and are located $8 \mathrm{~km}$ NE of 
Kingri town. Drug-Toi Nala-Savi Ragha-Zamaray (Musakhel) gypsum deposits show $55 \mathrm{mt}$ and are located on eastern boarder of Musa Khel district. The area is accessible from Taunsa and Vihowa areas of D. G. Khan district. Giandari-Harand-Sakhi Bor Bakhsh-Khan (Rajanpur) Gypsum deposits show $33 \mathrm{mt}$ and are located on Foot Mountains of eastern Sulaiman foldbelt. These deposits are accessible from Rojhan, Rajan Pur and D. G. Khan. Rakhi Gaj-KhandorBarthi-Manka Fazla Kach (D. G. Khan) gypsum deposits show $44 \mathrm{mt}$ and are located on Foot Mountains of eastern Sulaiman foldbelt. Manjhail-Kharar Buzdar (D. G. Khan) gypsum deposits show $66 \mathrm{mt}$ and are located $35 \mathrm{~km}$ north of Rakhni. It is $100 \mathrm{~km}$ wsw of Taunsa Town. CaO content varies from $30.84 \%$ to $32.24 \%, \mathrm{SO}_{3}$ from $45.75 \%$ to $48.36 \%$, and $\mathrm{H}_{2} \mathrm{O}$ from $17.62 \%$ to $18.62 \%$. Zinda Pir anticline (D. G. Khan) gypsum deposits show $88 \mathrm{mt}$ and are located on the periphyry of Zinda Pir anticlines. These are accessible from D. G. Khan, Shadan Lund and Taunsa towns. Mughalkot-Ragha Sar-Khoara Khel (D. I. Khan) gypsum deposits show $44 \mathrm{mt}$ and are located on western limb of Drazinda syncline and accessible from D. I. Khan. Domanda-Drazinda-Drabin (D. I. Khan) gypsum deposits show $33 \mathrm{mt}$ and are located on faulted eastern limb of Drazinda syncline and accessible from D. I. Khan. Waziristan gypsum deposits may show about $5 \mathrm{mt}$ which are the extension of Shirani gypsum and are located on foothills of eastern Sulaiman foldbelt and accessible from D. I. Khan. The deposits of Sulaiman foldbelts are feasible due to availability of inexhaustable gypsum and favorable central locations. Vast Areas of saline land can economically be made productive again. So far gypsum is being produced from Punjab and KP. Balochistan has the largest gypsum deposits in Balochistan but not producing.

\section{Agromineral Resources from Pakistan}

The exploration for fertilizer resources/agrominerals like rock phosphate should be accelerated because Pakistan is an agricultural country and its demands are increasing. Further try should be made to explore and develop own resources and try to reduce import of phosphate/DAP.

Rock Phosphate: The solubility of phosphate in sea water increases with decreasing $\mathrm{PH}$ and temperature and for this reason concentrated in deep cold water. Black bituminous shale, chert and other siliceous rocks are best host of phosphate. The Mesozoic and Cainozoic strata of Indus basin show all these properties. The Tertiary, Cretaceous and Jurassic sequence in Sulaiman range were studied by [87]. They found phosphatic nodules with $5 \% \mathrm{P}_{2} \mathrm{O}_{5}$ in Domanda and Drazinda shales (Figure 1), which are encouraging for further study. The Rakhi Gaj area show nodules with 5\% - 20\% $\mathrm{P}_{2} \mathrm{O}_{5}$ and Zinda Pir area show 5\% $\mathrm{P}_{2} \mathrm{O}_{5}$ of D. G. Khan district in Sangiali group (Sangiali, Rakhi Gaj and Dungan formations) and lower Ghazij/Chamalang group (Shaheed Ghat shale). Phosphate nodules are found in about $20 \mathrm{~m}$ shale interval of probably Rakhi Gaj formation. Nodules with $<5 \%$ phosphate in Late Cretaceous Mughalkot formation in Karim Kach Khwar to the east of Kurgali (on Mughalkot and Dhana Sar road 
section) are found [87]. The Pabni Chawki and Naka Pabni were studied by [87]. It has been reported from the Cretaceous sequence near Kohat (Chichali Formation), near Chhoi in Kalachitta Range (Kawagarh Formation), Paleocene and Eocene rocks in the Salt range (Patala Formation), Eocene Chamalang group, and Paleocene Sangiali group (Sangiali and Rakhi Gaj formations) in the Sulaiman foldbelt, and Oligocene sequence in the Southern Kirthar range (Nari Formation). There is little or no economic value due to its low $\mathrm{P}_{2} \mathrm{O}_{5}$ content [5] but indicates for large deposits. Further try should be made because Pakistan is agricultural country and large money will be saved by reducing imports. The main deposits occur in Cambrian Abbottabad and Hazira formations and Precambrian Hazara Formation, northeast of Abbottabad, along the western flank of Hazara Kashmir syntaxes [88]. The Hazara deposits (Figure 1) covers an area of $155 \mathrm{sq} \cdot \mathrm{km}$. Phosphate occurs in cherty dolomite. The phosphorites are of pelletal type and commonly contain cellophane, dahlite, francolite, glaucophane, dolomite, iron oxide and pyrite in various proportions [88]. These deposits show two lithological types like cherty phosphorite of Abbottabad formation and silty calcareous phosphorite of Hazira Formation.

Kakul-Mirpur area covers $13 \mathrm{sq} \cdot \mathrm{km}$ area in the $9.5 \mathrm{~km}$ east of Abbottabad. The phosphorite horizon has a strike length of $516-607 \mathrm{~m}$ with average thickness of about $4.5 \mathrm{~m}$. In this region there are two phosphorite horizons, an upper one at the contact of Hazira and Abbottabad formations and a lower one in the cherty dolomite of Abbottabad formation. The host rocks are tightly folded and faulted. This deposit has $1.08 \mathrm{mt}$ with $\mathrm{P}_{2} \mathrm{O}_{5}$ content variation from $14 \%$ to $32 \%$ [88]. Kalue-de-Bandi and Lagarban area is $40 \mathrm{~km}$ northeast of Abbottabad. The phosphorite is found on the both limbs of syncline. Western limb has $3033 \mathrm{~m}$ and eastern limb $1062 \mathrm{~m}$ outcrop length with 3 to $8 \mathrm{~m}$ variable thickness. Southward near Kalue-de-Bandi, $32 \mathrm{~m}$ below the main deposit, another $305 \mathrm{~m}$ phosphorite horizon is exposed. The $\mathrm{P}_{2} \mathrm{O}_{5}$ content of these deposits varies from $19 \%$ to $39 \%$. The Kalue-de-Bande has $8.3 \mathrm{mt}$ with $\mathrm{P}_{2} \mathrm{O}_{5}$ content $24 \%-34 \%$. The Lagarban has high grade $0.3 \mathrm{mt}$ ore with $\mathrm{P}_{2} \mathrm{O}_{5}$ content $31 \%$ and low grade $1.7 \mathrm{mt}$ ore with $\mathrm{P}_{2} \mathrm{O}_{5}$ content of about $21 \%$. Dalola area is located $6 \mathrm{~km}$ south of Garhi Habib Ullah. There are three phosphorite horizons in the Hazira Formation with length of 1692, 152 and $303 \mathrm{~m}$ with variable thicknesses of 3 to $23 \mathrm{~m}$. This deposit is different from others. It is black, dense, silty, calcareous, cherty, non pelletal and contains small amounts of manganese. The reserves are $9.2 \mathrm{mt}$ with variable $\mathrm{P}_{2} \mathrm{O}_{5}$ content $9 \%$ to $17 \%$. Sirban Hill area; It is $6 \mathrm{~km}$ from Abbottabad and has $455 \mathrm{~m}$ strike length and 3.9 to $3.6 \mathrm{~m}$ thickness. The reserves are $1.9 \mathrm{mt}$ with variable $\mathrm{P}_{2} \mathrm{O}_{5}$ content $3 \%$ to $25 \%$. In Minind area, the SDA developed a mine near Kakul. A crusher was also installed at site and material was supplied to the National Fertilizer Corporation (NFC) at their Haripur Plant. Further ground rock phosphate was also supplied to NFC plant at Jaranwala. The SDA developed another mine at Rehala in the Tarnavi-Lagarban area for supply of 60,000 ton of rock phosphate to NFC Haripur Plant annually. The reference [89] reported 
phosphate $(25 \%-40 \%)$ associated with chert in Cambrian rocks of Abbottabad and Hazira/Galdanian formations from Soban Gali, Paswal Mian, Banseri and surrounding areas in district Abbottabad, which are $25 \mathrm{~km} \mathrm{~N}$ of Abbottabad on Abbottabad-Sherwan road.

The Iron and phosphate from Rakhi Gaj formation (Gorge beds) has anomalous iron (14\% - 21\%) deposit, while phosphate from green and black shale and greenish grey sandstone of Mughalkot formation and green to greenish grey shale and greenish grey to red spotted and red wavy laminated sandstone of Rakhi Gaj (both Girdu and Bawata members) formation. Phosphate is reported from Rakhi Gorge (Sangiali and Rakhi Gaj Formations) and Mari-Bugti hills phosphatic nodules in Cretaceous Pab formation and also black and green shale and sandstone of Mughalkot formation of Gharwandi (Alu Khan Kach) areas [14] [19]. The reference [90] reported phosphate (apatite; $\mathrm{P}_{2} \mathrm{O}_{5} 2.5 \%-12.6 \%$ ), along with rare metals and REEs from Loe-Shilman complex of Khyber Agency.

Rock Salt: Its mineral is halite (sodium chloride) formed by evaporation of sea water in restricted shallow basins. Chemical analyses of Khewra rock salt show $\mathrm{NaCl} 98.65 \%, \mathrm{CaSO}_{4} 0.41 \%, \mathrm{MgSo}_{4} 0.40 \%, \mathrm{Na}_{2} \mathrm{SO}_{4}$ 0.24\%, moisture 0.11\%, insolubles $0.03 \%$, undetermined $0.16 \%$ [91]. It occurs as large deposits in Slat Range Formation of Precambrian age in Punjab and Eocene Bahadur Khel Salt Formation in KPK. Geological Survey of Pakistan (GSP) proved inexhaustible reserves of rock salt (Figure 1) in Salt Range [92]. The present annual production is more than 106,000 ton. It is used in the country. About $40 \%$ is used for Soda ash, caustic soda and leather industries and rest is marketed for human consumption. A certain amount of rock salt has been exported to Afghanistan and India from time to time. It is being produced from Punjab and Khyber Pakhtunkhwa/KP. The verbal thought of rock Salt of Salt range is being smuggled to India where they get lot of benefits on export. So the federal and provinces governments may reduce or end this smuggling and further should promote the own country salt exports.

Potash Salt: Potassium salts $\left(\mathrm{K}_{2} \mathrm{O} 9 \%-14.4 \%\right)$ seams are associated with rock salts in Slat Range Formation [4] of Precambrian age in Punjab and Eocene Bahadur Khel Salt Formation in KP [93]. So far brine is being produced from Punjab.

Gypsum: It has multi-uses like soil conditioning, cement resources, etc. Pl. sees in cement resources.

Limestones: Pakistan has vast deposits of marl and limestone (Figure 2) which can be used as fertilizer for the fertility of agricultural lands in Pakistan. Its agricultural application is negligible and demands for vast usages in Pakistan.

Shale: The shale with anomalous phosphate of Rajan Pur, D. G. Khan and D. I. Khan regions (eastern part of Sulaiman Range) can be used for ceramics, cement resources and directly for fertility of lands.

Nitrogen: It is found in the air. It is being used for Urea production. Pakistan should increase the urea industry due to agricultural country. 


\section{Marble, Construction, Dimension and Décor Stone (Decorative Stone) Resources from Pakistan}

These are extensively used in the construction industry, for decorative purposes in building facings, bath rooms and for floor tiles. It is used for making handicraft items. To develop the marble and granite sector of Pakistan to make it a competitive player of the international dimension stone market, Pakistan Stone Development Company (PASDEC) has been established to use modern technology, reduce stone wastage from $85 \%$ to $45 \%$ and to enhance the processing facilities in the country for value addition to earn foreign exchange [94]. The large quantity of marble, limestone (Figure 2), granite, gabbro, dolerite, sandstone, conglomerate, aggregate/gravel and clays/shale (Figure 2) resources are found in different areas and provinces of Pakistan. The most commonly used are simple marble, onyx or banded marble, various types of limestones and igneous rocks, mainly granite, dolerite etc. Vast marble deposits were reported from Pakistan [95]. Large reserves of recrystallised limestone and marble occur widely in the Gilgit and Skardu region, in Chitral, Azad Kashmir, Balochistan and Swat, Mardan, Bajaur and Khyber districts of KP [96]. Vast reserves of high quality onyx marble are found in Chagai district of Balochistan province [5]. This marble has been mined extensively and besides local consumption, it has been exported in great quantities. Attractive and good quality granitic rocks occur in Gilgit, Chitral, Swat, Hazara, Raskoh, Las Bela, and Nagar Parker areas. Milk white granite has been mined from a locality $18 \mathrm{~km}$ north of Gilgit. Pink granite of Nagar Parker areas are relatively close to industrial city Karachi. Granite is being produced from KP, Sindh and Balochistan. Large reserves of good quality gabbro are found in Muslimbagh-Nisai area. Dolerite dykes from several localities provide jet black slabs for tiles and wall facings. Several kinds of agglomerate (igneous conglomerate with angular fragments) multicolored, brecciated rocks are mined from the Bela and Kanar mélanges in Bela-Khuzdar area. Serpentine is found in the western and northern Indus Suture zones as large deposits. It is being produced from Balochistan and KP. Large deposits of slate stone are found in Balochistan (flysch basin), and KP and being produced so far from KP. These are being mined and marketed under erotic trade names such as Golden, Trevera, Boutecenne, Verona, Black and Red Zebra, Oceanic etc. The private sector exclusively deals with the production, processing and marketing of marble and other decorative stones. Malkani reported huge deposits (more than one billion ton) and Dungan limestone/marble (white) in the Kasa and Karu areas of Loralai district, which is being well used as marble for the preparation of many types of tiles. Further it is found in the districts like Loralai (Kasa, Karu and Anambar area; 39F/3, 39B/11, 39B/15; [14] [19]), Barkhan, Musa Khel, Kohlu and Dera Bugti. Large reserves of recrystallised limestone and marble occur widely in the Sulaiman Basin. Several varicoloured varieties of fossiliferous limestone hosting fossils and shells of foraminifers, mollusk, etc. Many limestones have multicoloured calcite veins extensively occur in the Mesozoic and Cenozoic sequences. 
Very small showings of low weight travertine/aragonite are found in the vicinity of hot water springs area like Anambar, Mahiwal and Karu of Loralai area. The aragonite thin beds are also found in the Shaheed Ghat shale in the Rakhni and Sham, Kulchas, Phailawagh and other areas of Dera Bugti district and also in other parts of basin. The large reserves of bed rock resources like shale, sandstone, limestone (Figure 1) (Figure 2), slatstone, quartzite, etc and the aggregate resources like gravel, grit, sand, clay, etc are observed. Building stones like Limestone from Chiltan, Loralai, Parh, Mughal Kot, Fort Munro, Sangiali, Dungan, Drug, Habib Rahi and Pirkoh formations, sandstone from Sembar, Pab, Vitakri, Sangiali, Toi and Kingri formations and Vihowa group; and. gravel and sand from Pliocene Chaudhwan, Pleistocene-Holocene Dada group (Dada and Sakhi Sarwar formations), and Subrecent and Recent terrace and fan deposits are significant. The crushing plants of Sakhi Sarwar (D. G. Khan) are using well the Quaternary, Holocene, subrecent and recent gravels. Vast and huge deposits of easily mineable (200 $\mathrm{m}$ depth to exposed surface) limestone, sandstone and shale of Sulaiman, Kirthar and Balochistan basins are presently estimated (Figure 2) as the limestone deposits are round about 1207 bt with breakup as Jurassic 490 bt, Cretaceous 77 bt, Paleocene 18 bt, and Eocene 622 bt; the shale deposits are 5799 bt with breakup as Jurassic 33 bt, Cretaceous 418 bt, Paleocene 27 bt, Eocene 4131 bt and Oligocene-Pliocene 1190 bt; the sandstone deposits are $5887 \mathrm{bt}$ with breakup as Cretaceous 1327 bt, Paleocene 17 bt, Eocene 953 bt and Oligocene-Pliocene 3590 bt (Figure 2). Further the eastern parts of Khuzdar district host the very large and good quality Paleocene Dungan limestone especially Mandhre Jove (more than 1 billion tons), Kharzan (more than 1 billion tons), Karkh (more than 1 billion tons) areas and Jurassic Zidi limestone (more than 5 billion tons).

Further Chalk is being produced from Sindh. Conglomerate and gravel is being used in South Punjab (Sakhi Sarwar, D. G. Khan, Saraikistan) and Balochistan. Large quantities of thick and different coloured shale/clays of different ages are found in Pakistan. The reference [97] mentioned slates from Attock-Cherat range for use as structural lightweight concrete aggregate. Marble waste can be used like marble cuttings can be used as marble chips, marble powder as filler in rubber and plastic industry, marble sludge can be used making building blocks. The disposal of marble waste on land and into water bodies can be stopped and ensure the extraction of geometrical shapes and size of marble blocks through scientific mining [98]. Further recently author found limestone deposits in Lamnian area of Hattian district, Azad Kashmir can be used for construction materials and also for cement industry. Some beds of sandstone of Murree formation in Azad Kashmir can be used for construction materials. Marble deposits have been found in the Nauseri and Jhugian areas of Lower Neelam valley, Muzaffarabad District, Azad Kashmir, Pakistan. These Marble deposits are product of metamorphism in the dolomitic limestones of Paleozoic-Mesozoic Abbottabad-Kingriali-Samanasuk-Panjal formations. By tectonic setting these marbles 
are sandwiched between Main Boundary Thrust and Khairabad-Panjal Thrust. Marble deposits are found on the eastern limb of Hazara-Kashmir syntaxis. The Nauseri marble area is located on Muzaffarabad-Neelam metalled road about 25 $\mathrm{km}$ east north east of Muzaffarabad city, while Jhugian Naka area is on the top of slender ridge trending toward Mahandri, Kaghan area (plunge of Hazara Kashmir syntaxis). These deposits are accessible from Muzafarabad, while Muzaffarabad is well connected with Islamabad and Abbottabad. On reconnaissance visit to see the generalized extension, these deposits are pinching toward Mahandri, Kaghan valley and also pinching towards Lamnian, Reshian valley. The marble is white, faint little blue tinge, translucent, pearly, massive and recrystallised. Two horizons of marble deposits are found in the Nauseri-Jhugian area of Muzaffarabad. The upper horizon is relatively thin while the lower horizon is relatively thick and workable/mineable. The lower horizon is thicker and being mined on the top of Nauseri-Jhugian area and being transported from top to base camp by motor driven rope and shovel systems. From base camp it is being transported further in the trucks to the market. This marble gives effervescence on acid drops confirming calcareous limy nature. The chemical results show $\mathrm{SiO}_{2}$ 10.34\%, $\mathrm{Al}_{2} \mathrm{O}_{3}$ 0.34\%, $\mathrm{Fe}_{2} \mathrm{O}_{3}$ 0.17\%, $\mathrm{CaO}$ 32.54\%, $\mathrm{MgO}$ 21.21\%, $\mathrm{Al}_{2} \mathrm{O}_{3}$ 0.34\%, $\mathrm{TiO}_{2} 0.027 \%, \mathrm{P}_{2} \mathrm{O}_{5} 0.001 \%$, Loss on ignition $35 \%, \mathrm{Na}_{2} \mathrm{O}$ and $\mathrm{K}_{2} \mathrm{O}$ are below detection limit [74]. The chemical as well as petrographic study shows dolomitic limestone metamorphosed as marble which constitute the mineral composition as calcite $60 \%$, dolomite $30 \%$, Feldspar $8 \%$ and quartz $2 \%$. This white marble gives high reflectance and has great significance as good quality. Due to small deposits of such high reflectance and good quality marbles in the country is in high demand in Pakistan and also abroad like Saudi Arabia and Arab Emirates, etc. The present findings are highly valuable in mineral wealth of Azad Kashmir and consequently for Pakistan. Its development alongwith other mineral commodities of Azad Kashmir is an innovation for the sustainable development of Azad Kashmir. Considering 2 kilometer length and about 10 meter thickness and 1kilometer easily mineable depth, the total easily mineable reserves are 56 million tons. Both horizons of marble are enveloped by igneous intrusions and volcanics of Panjal Group. This magma/lava is responsible for the metamorphism and birth of high quality with good reflectance marble in this area.

Dolomite: Dolomite occurs in Precambrian Salt Range Formation, Cambrian Jutana and Khisor formations, Devonian Shagai limestone, Triassic Kingriali Formation, Jurassic Samanasuk and Takatu (Chiltan) limestones and Eocene Chorgali Formation. The Karakoram block has Devonian Kuragh dolomite sequence. The major dolomitic deposits are Kachi Haripur (Abbottabad Fm. Large), Sherwan (Abbottabad Fm. Large), Wagh (Precambrian, MgO 21.02\%, $\mathrm{CaO} 31.43 \%$, Large), Nilawahan (Salt Range Fm. MgO 19.72\%, $\mathrm{CaO} 28.71 \%$, Large), Saidu Wali Khisor Range (Salt Range Fm. MgO 20.11\%, CaO 31.05\%, Large), Ghundai Tarako Mardan (Paleozoic, $\mathrm{MgO}$ 19.21\%, $\mathrm{CaO} 31.33 \%$ ), Khyber Agency (Khyber Fm., Shagai limestone, MgO 20.01\%, CaO 30.1\%, Large), 
Kuch Kalabagh (Kingriali Fm. MgO 21.8\%, $\mathrm{CaO} 30.8 \%, 0.5 \mathrm{mt}$ ), Makarwal (Datta, Doya-Lunda, Narmia-Punnu) (Kingriali Fm. MgO 20.2\% - 21.6\%, CaO 28.9\% - 31.3\%, $900 \mathrm{mt}$ ), Burikhel Mianwali (Kingriali Fm. MgO 16.8\%, CaO $31.5 \%$, Large), Kalachitta (Very Large), Kohat, NW of Pail (MgO 17.95\%, CaO 26.32\%, Large), Chiltan Range-Ziarat Nala (MgO 20\%, CaO 32\%, $250 \mathrm{mt}$ ).

Igneous and Metamorphic rocks: Igneous along with some metamorphic rocks are found in the Indo-Pakistan shield (Nagar Parker, Kirana and Khyber-Hazara crystalline zone), Western and Northern Indus Suture, Balochistan magmatic arc, Kohistan magmatic arc and Karakoram block. These large deposits of igneous rocks can be used for construction and other purposes. Igneous rocks like granite, gabbro, dolerite, serpentine, agglomerate are being used.

Marble, Construction, Dimension and Décor Stone Resources and shale of South Punjab (Saraikistan/Saraiki Province): South Punjab has very large deposits of dimension and construction stones like limestone, dolomite, sandstone, shale, conglomerate and gravels from Sulaiman Range and its foot mountains. Vast deposits of sand are found in Indus river and its tributaries. Building stones like Limestone from Fort Munro, Dungan, Drug, Habib Rahi and Pirkoh formations, sandstone from Pab, Vitakri and Rakhi Gaj formations and Chitarwata, Litra and Chaudhwan formations of Koh Sulaiman Range have been reported. Gravel and sand from Chaudhwan, Dada, Sakhi Sarwar formations, Subrecent and recent surficial deposits in the Sakhi Sarwar and its vicinity are significant. Further vast deposits of gravel are found as terrace and fans and in channels/streams. The D. G. Khan areas show limestone reserves (Figure 2) (from exposure to $200 \mathrm{~m}$ depth) are 1 bt of Maastrichtiam Fort Munro limestone, 1 bt of Paleocene limestone and 50 bt of Eocene Drug, Habib Rahi and Pir Koh limestones. The shale reserves (Figure 2) are 5 bt of Cretaceous (Mughal Kot, Fort Munro, Pab and Vitakri formations), 10 bt of Paleocene (Sangiali, Rakhi Gaj and Dungan formations) and 500 bt of Eocene Shaheed Ghat, Drug, Baska, Domanda and Drazinda formations, and sandstone reserves (Figure 2) are 500 bt of Cretaceous Pab and Vitakri formations, 7 bt of Paleocene Sangiali and Rakhi Gaj formations and 500 bt of Oligocene Chitarwata, Miocene Vihowa and Litra, Pliocene Chaudhwan Formations. The Rajan Pur areas show limestone reserves (Figure 2) (from exposure to $200 \mathrm{~m}$ depth) are Maastrichtian Fort Munro limestone (1 bt), Paleocene Dungan limestone (5 bt) and Eocene Drug, Habib Rahi and Pir Koh limestones and marls (30 bt). The shale reserves (Figure 2) are 1 bt of Cretaceous, 5 bt of Paleocene, 400 bt of Eocene strata, and 50 bt of Oligocene-Pliocene strata, and sandstone reserves (Figure 2) are 200 bt of Cretaceous, 2 bt of Paleocene and 400 bt of Oligocene to Pliocene strata. Limestone is extensively used as crushed stone for concrete aggregates, road metal and rail road ballasts, cement, fluxing agent, soil conditioner, as a source of lime, chemical raw material and as dimension stone, building, statuary, monumental and ornamental purposes, making animal feed, manufacture of glass and soda ash (sodium carbonate), acid gas removal and sugar refining with tight specifications 
and high grade Large reserves of limestone (commonly used marble) occur widely in the Sulaiman Range. Further Maastrichtian Fort Munro limestones of eastern limb of Fort Munro-Maarri anticlinorium and late Paleocene Dungan limestone of Harand, Maarri, Chacha-Beaker-Kalchas can be used as dimension stones and tiles preparation. Zinda Pir deposit is found in the core of Zinda Pir anticline and also easily accessible from D. G. Khan and Shadan Lund. D. G. Khan cement industry is also using this Dungan Limestone. The beautiful amorphous silica, beautiful pebbles and cobbles, chalcedonic silica like chert, flint, jasper, etc, are found as detritial in placer deposits like conglomerate and conglomeratic sandstone/gritstone of Oligocene Chitarwata, Miocene Vihowa and Litra and Pliocene Chaudhwan formations of Vihowa Group and also in the Pleistocene Dada conglomerate and Holocene Sakhi Sarwar formations of Sakhi Sarwar Group and also in the terrace and present day river/streams/channels in the eastern Sulaiman Range. These are significant for jewelry resources found relatively easy.

Ceramic Mineral Resources from South Punjab (Saraikistan/Saraiki Province), Pakistan: Vast ceramic mineral resources like various types of clay deposits are found from Chamalang/Ghazij, Kahan and Vihowa groups of Sulaiman Foldbelt. Bentonite is non swelling type of clay with white, grey and brown colours and high calcium percentage. For swelling type, it is converted into sodium bentonites by Base Exchange process. Origin of bentonite is redeposition of decomposed volcanic ash, tuffs and lavas. Presently it is also observed in the eastern foothills of Sulaiman range of Rajan Pur and D. G. Khan districts. The upgrading of bentonite by using Carboxymethyl cellulose and soda ash addition, it can be used for drilling as well as leakage control. Fuller's earth is nonplastic clay usually contain appreciable magnesia. It is valued for its decolorizing and purifying properties, vegetable oil and ghee industries, refining of oil and fats, insecticide, foundries and steel industries. The main producers are D. G. Khan. Fuller's earth is formed in the flood plains of Tertiary river channels. It is greenish grey, bluish grey and greenish brown clay with soapy feel. Thick immense reserves of fuller's earth upto $30 \mathrm{~m}$ thick observed by Hilal A. Raza in Domanda and Baska formations in Rakhi and Sebdi nalas in southern Sulaiman Range. The present research shows its thick immense reserves of fuller's earth are found in Domanda and Baska formations in eastern Sulaiman foldbelt. The samples of fuller's earth from Domanda and Drazinda shales (Zin area) and eastern limb (Mahoi area) of Zinda Pair anticline, Tehsil Taunsa, Dera Ghazi Khan District and their chemical results show $\mathrm{SiO}_{2} 50.86 \%$ to $64.01 \%, \mathrm{Al}_{2} \mathrm{O}_{3}$ 9.79\% to $17.18 \%, \mathrm{Fe}_{2} \mathrm{O}_{3} 3.10 \%$ to $6.89 \%, \mathrm{CaO} 6.41 \%$ to $12.20 \%, \mathrm{MgO} 2.01 \%$ to $5.64 \%, \mathrm{P}_{2} \mathrm{O}_{5} \mathrm{Nil}$ and loss on ignition/volatiles $8.87 \%$ to $12.60 \%$. Present author estimated reserves of $10 \mathrm{mt}$ upto 200 meter easily mineable depth in Zinda Pir anticline areas. Huge reserves of fuller's earth are observed in Domanda, Drazinda and Baska formations in eastern Sulaiman Range. The possible Fire clay from Chitarwata, Rakhi Gaj, Vitakri, Drazinda formations and Vihowa group of 
eastern Sulaiman Foldbelt seems to be significant. Present author estimated reserves of $10 \mathrm{mt}$ upto 200 meter easily mineable depth in Zinda Pir anticline areas and more than 1 billion ton in eastern Sulaiman Range. Fire clay is resistant to shrinkage, abrasion and corrosion under high temperature and withstands thermal spalling. It is very low in iron oxide content $<2 \%$ and high in alumina $(24 \%-45 \%)$. The main area of production is D. G. Khan district. It is found at Kot Kaisrani (D. G. Khan) in the Sulaiman Rabge. In actual the fire clay and fuller earth deposits are same (as mentioned in fuller earth) being mined from many places at Kot Kaisrani, Mahoi, Zin, etc. The fire clay beds are associated with many coal horizons. The ochre, limonite, iron, fire clay from Chitarwata, Rakhi Gaj, Vitakri, Drazinda formations and Vihowa group of eastern Sulaiman Range seems to be significant. Large deposits of silica sand in Pab Formation and Vihowa group (mostly in Chitarwata Formation especially in Zinda Pir area), and large deposits of porcellaneous limestone and marl and shale (Figure 2) occurred in of D. G. Khan and Rajan Pur districts.

Geo-assetts of South Punjab (Saraikistan/Saraiki Province): South Punjab has vast cement resources like limestone (Fort Munro and Dungan limestones, Eocene limestones and marl), gypsum from Baska Formation and shales from Shaheed Ghat, Domanda and Drazinda formations and Vihowa group, construction, dimension and decorstones from alluvium and also from bed rocks, various types of clay deposits like bentonite, fuller's earth and fire clay, surface and ground water resources, uranium, petroleum, coal, hot springs (Garmaf and Zinda Pir Ziarat) and many other minerals like abrasives from gritty Pab sandstones and millstones from hard Pab sandstones. The Rakhi Gaj area show nodules with 5\% - 20\% $\mathrm{P}_{2} \mathrm{O}_{5}$ and Zinda Pir area show 5\% $\mathrm{P}_{2} \mathrm{O}_{5}$ reported from Sangiali group (Sangiali, Rakhi Gaj and Dungan formations especially green and black shale and muddy strata) and Shaheed Ghat shale. The phosphatic nodules with $5 \% \mathrm{P}_{2} \mathrm{O}_{5}$ reported in Domanda and Drazinda shales. Phosphate nodules are found in about $20 \mathrm{~m}$ shale interval of probably Rakhi Gaj Formation. The agromineral resources like phosphate showings and alum shales are encouraging for further exploration because South Punjab is agricultural centre of Pakistan. The possible low grade but large deposits of ochre/iron (may contains alluminium) found from Chitarwata, Vihowa, Rakhi Gaj, Vitakri and Drazinda formations may be used for paint and abrasive and other purposes. The celestite mineral showings are found in the Eocene limestone of D. G. Khan and Rajan Pur areas. The heavy and resistant minerals like ilmenite, magnetite, gold, sheelite, rutile, zircon, monazite (REE bearing), gold, etc. and many gemstones and jewelry resources found easily in placer deposits of Indus River and Oligocene to recent alluvial deposits. The beautiful detritial pebbles and cobbles, amorphous or chalcedonic silica like chert, flint, jasper, etc., found in the conglomerate and gritty sandstone of Oligocene Chitarwat, Miocene Vihowa and Litra and Pliocene Chaudhwan formations of Vihowa Group and Pleistocene Dada and Holocene Sakhi Sarwar formations of Sakhi Sarwar Group and recent river and 
flood plain areas. Low grade iron deposits $\left(\mathrm{Fe}_{2} \mathrm{O}_{3} 14 \%\right.$ - 21\%) found as ferruginous sandstone with minor shale in Girdu (Gorge beds) member of Rakhi Gaj formation of Khar Fort Munro, Top Girdu, Mian Ghundi, Rakhi Gaj, Bawata, Kingri, Badhi, Chitri areas. The greenish grey and red spotted and red wavy laminated sandstone show iron (alongwith phosphate) mineralizations and bivalve shell of Rakhi Gaj Formation. The hematite and possibly hydrous iron silicates (chamosite and glauconite) are major iron mineralization and may be derived from Deccan volcanism. It's testing for steel, cement and other industries should be make and may prove worthy. The extensive iron beds thickness varies from 2 to $50 \mathrm{~meter} / \mathrm{m}$. Its reserves seem to be 400 million tons from surface exposure to easily mineable depth $200 \mathrm{~m}$. Its mining is easy due to exposure above the ground surface, and at places low dips. The Fort Munro iron deposits seems to be favorable due to availability of huge but low grade raw materials, open pit mining, locations on metalled road and near to D. G. Khan railway station, central Pakistan. The Sulaiman Koh Range of South Punjab and adjoining Balochistan yielded the fossils of walking whales [99] and basilosaurids-king of the basal whale [100] [101], rhinoceros baluchitheres-the largest land mammals [101], sauropod dinosaurs [102]-[114] like Gspsaurus pakistani [102] and Saraikimasoom vitakri [103] gspsaurid stocky poripuchian titanosaurs and Pakisaurus balochistani [104] and Sulaimanisaurus gingerichi (Isisaurus colberti) [104] [110] pakisaurid slender poripuchian titanosaurs, large theropod dinosaurs [110] [115] [116] like Vitakridrinda sulaimani [116] and Vitakrisaurus saraiki [116], mesoeucrocodiles like Induszalim bala [116], Sulaimanisuchus kinwai [116] and Pabwehshi pakistanensis [117], and flying reptiles pterosaurs like Saraikisaurus minhui [101] [116] and many other terrestrial and marine biotas [101]. Besides fossils, many footprints and trackways of small and large theropods [101] [108] [118] and herd of herbivorous dinosaurs [101] [108] [118] and titanosaurian sauropods [101] and pterosaurs [116]. All these geoassetts needs protection and proper display in safe and easily accessible places.

\section{Gemstone and Jewelry Resources from Pakistan}

Pakistan has vast deposits of precious and semi-precious gemstones [5] [8] [25] [119] [120] [121] [122] like Gilgit Baltistan, Khyber Pakhtunkhwa, Azad Kashmir, Balochistan, North Punjab, South Punjab (Saraikistan), and Sindh (Figure 3). The gemstones and jewelry resources are represented as gold-silver-platinum, emeralds, rubies, topaz, quartz, aquamarine, garnet, tourmaline, peridot, moonstone, pargasite, fluorite, corundum, sapphire, spinel, kyanite, vesuvianite, quartz, flint, chert and jasper, green, bicolour and tricolour tourmalines, spessartine garnet and morganite. A verbal thought is known that the majority of these gemstones and jewelry resources are smuggled directly to India or via $\mathrm{Du}$ bai (UAE) to India, Thailand, Burma, etc. If true, then the government may reduce or end this smuggling and should promote the own country gems and jewelry industries like jewellery manufacturers, lapidaries, gemstone dealers and 
gem miners to increase their exports, new jobs, remittances, and exchequer [94].

\subsection{Gemstone and Jewelry Resources from Khyber Pakhtunkhwa (Including FATA), Pakistan}

The gemstones and jewelry resources of Khyber Pakhtunkhwa including FATA are being presented (Figure 3).

Gold-Silver-Platinum: Gold deposited by hydrothermal, metamorphic and replacement deposits and also nuggets and grains in residual or placer deposits. The silver used as photographic materials, in refrigeration and air conditioning industries. It is associated with copper, lead, zinc deposits or in combination with gold. Platinum group metals are used in automobile industry to reduce $\mathrm{CO}$ emission, in chemicals, petroleum refining, ceramics and glass, electrical and electronic industries, in jewelry, in dental and medicine like treatment of cancer, arthritis, radiotherapy, production of denture, etc. Platinum group are associated with mafic and ultramafic rocks, also in placers. Small amount of gold is also recovered by panning in the upper Indus and its tributaries. The production of copper along with gold will be started soon from Saidak porphyry copper deposits. The references [123] [124] reported alluvial gold and mineral in Chitral and Northern areas respectively. In Northern areas under Gold Exploration carried by Australian Assistance during 1992-95 by geochemical samplings. Gold was detected in many hundreds of drainage tributaries. Among these 24 sites shows high anomalous gold. These anomalies are mostly associated with major shear zone/Indus Suture and some are porphyry type intrusives or altered carbonates [125].

The upper reaches of Chitral, Gilgit and the Indus River in northern parts of Pakistan are well known for the placer gold occurrences [126]. The Bagrot valley [127], Shigari Bala area of Skardu [128] and Golo Das and surrounding areas [129] of Gilgit-Baltistan seems to be significant for gold and base metal mineralizations. Chitral district was studied by SDA for gold and silver prospects in the Sewakht formation of [130] in the Awireth-Shogor-Sewakht areas of Chitral, 6 $8 \mathrm{~km}$ west, northwest and north of Krinj. This formation is faulted on both sides. To the east the Reshun fault separates it from Krinj limestone and to the west it is faulted against Lutkho Formation along the Pasti fault. This formation comprises of greenschist, limestones, ferruginous dolomitic carbonate, phyllite, sandstones and breccias. This prospect contains significant amount of boulangerite, which mainly consists of antimony, lead, gold and silver. Boulangerite samples from Shoghor show gold upto $56 \mathrm{gm} /$ ton silver upto $700 \mathrm{gm} /$ ton and antimony upto $20 \%$. The ferruginous dolomitic carbonate bed shows appreciable amount of gold and silver. The area is $25 \mathrm{~km}$ long and $16 \mathrm{~m}$ wide between the Sewakht and Awireth. The detail study by SDA with adits and channel samplings was carried for gold and silver. It reveals 50,000 tons of boulengerite with gold upto $70 \mathrm{gm} /$ ton and silver upto $180 \mathrm{gm} / \mathrm{ton}$. The estimated reserves of gold and silver bearing ferruginous carbonates are about $50 \mathrm{mt}$ [131]. Dir district was stu- 
died for gold, silver and copper anomalies in the Dir volcanic group near Zaluka village, $250 \mathrm{~km}$ north of Peshawar [132]. The host rock show subporphyritic to porphyritic sequence. Here is a $6 \mathrm{~m}$ wide alteration zone containing visible malachite and azurite. It also includes covellite, bornite and chalcocite. 12 samples yielded 3 - 11 ppm gold, 6 - 200 ppm silver, 1\% - 6.5\% copper and $30-198$ ppm lead. Chondrite is a stony meteorite contains chondrule (small rounded bodies of olivine or enstatine) embedded in a fine grained matrix of pyroxene, olivine and nickel-iron. Besham area shows PGE associated with gold near Besham in the Jijal layered ultramafic complex [133]. The layer/zone-1 include chalcopyrite, bornite, pentlandite, supergene violarite and magnetite in rocks, clinopyroxene with $10 \%-15 \%$ bronzite, $2 \%$ - 3\% disseminated sulphide with precious metals in ppb like Au 18 - 46, bronzite, 2\% - 3\% disseminated sulphide with precious metals in ppb like Au 18 - 46, Pt 56 - 90, Pd 47 - 70, Rh < 2 and total PGE $246-249$. The layer/zone-2 includes pyrrhotite, pentlandite, chalcopyrite as inclusion in chromite and clinopyroxene in rocks. Wehrlite and chromite/chromitite and dunite with precious metals in ppb like Au 35 - 275, Pt 99 - 402, Pd 40 - 720, Rh 2 - 10 and total PGE 365 - 1405. The layer/zone-3 include chalcopyrite, pyrrhotite, pentlandite, lesser pyrite and millerite, tetraauricuprite and atheneite in rocks hornblende-clinopyroxenite-ilmenite-postcumulus garnet with precious metals in ppb like Au 76 - 2457, Pt 15 - 715, Pd 144 - 2275, Rh $<2$ - 3, and total PGE 293 - 3597. The layer/zone-4 include chalcopyrite, bornite, clinopyroxene cumulate in rocks Garnet hornblendite with precious metals in ppb like Au 7 2130, Pt 64 - 221, Pd 80 - 417, Rh < 2 and total PGE 647 - 2284. The layer/zone-5 include pyrite, chalcopyrite, bornite, millerite, pentlandite in sulphide cumulate in garnet-gabbro (5\% - 10\% sulphide) with precious metals in ppb like Au 339, Pt 723, Pd 1730, Rh < 2 and total PGE 278 [133].

Aquamarine: It is a silicate of beryllium and aluminum and belongs to beryl group. It is reported from Lutkho valley Chitral [119], Talash Dir [5], Indus Kohistan and Kaghan valley [119]. It occurs in the pegmatites of NW Himalayas. Deeper colour varieties occur at Gabor-o-Bakh in Chitral. These areas have good potential for deeper blue colour, high priced aquamarine and merits further exploration and development.

Emerald: It is a member of beryl group. It is fancied for its clear dewy green. It is due to Chromium content and in fact a green beryl without chromium would not be accepted as an emerald. Emerald is believed to posses healing power and to some people it is known as the healing stone. Mingora, Gujarkilli and Shamozai areas of Swat District are well known producers of quality emerald. It is found in ophiolitic rocks of mélange zone of northern Indus Suture. Mangora emerald deposits are located in the northern edge of Mingora city. Two parallel north trending faults run through the area are believed to be the main conduits for mineralizing solutions. The reference [120] described the finest emeralds in the world. The stone is famous for their brilliant, medium to deep green colour as well as their unique transparency and are comparable to the fin- 
est Colombian specimens from Muzo. The average size distribution of emeralds in production is approximately of the following order [134]. Mellee (45.8\%), 0.5 - 1 carats (ct) (32.7\%), $1-2 \mathrm{ct}(6.8 \%)$ and above $2 \mathrm{ct}$ (14.7\%). Average grade size distribution show grading as excellent (5\%), very good (12\%), good (25\%), fair (13\%), and Melle (45\%). Gujarkili emerald deposits are located $24 \mathrm{~km}$ ENE of Mingora, $12 \mathrm{~km} \mathrm{SSW}$ of Alpurai in Swat district. The deposit covers an area of about 10 acres. A number of northwest trending faults with cross-cutting fractures and joints cut through the mineralized block and the emerald industry largely occurs along these faults and fractures. Emerald production has been increased from 5939 cts (1986-87) to 78,330 cts (1990-91). Emeralds crystals are dark green euhedral upto $100-2000$ cts in weight. Shamizai emerald deposits are located $24 \mathrm{~km}$ west of Mingora at altitude of about $1500 \mathrm{~m}$. The mineralization is traceable about $2 \mathrm{~km}$ along general strike. It occurs in talc-carbonate schists of Indus Suture Melange under geological conditions very similar to Mingora and Gujarkili. Emeralds are transparent with good green colour. Ann oddity reported from this mine is the presence of bicolor emeralds. Private company has intermittently mined the deposit. Other emerald deposits occur at Dandao Kandao, Nawe Dand, Gandao Kot and Mora Dara in Mohmand Agency, Arang Barang in Bajaur Agency, Makhad and Charbagh in Swat District. In short it has great potential for enhancing emerald production and mining activities in Mingora, Gujarkili, Shamozai and introducing new mines in Mimola and Mor Darra region (Barang) of Bajaur Agency. More emerald deposits can be discovered in $150 \mathrm{~km}$ long belt of northern Indus Suture between Indus and Mohmand Agency.

Garnet: The more common minerals are Pyrope (glowing red colour), almandine (brownish red to reddish violet colour), rhodolite (rose red colour and strong luster), spessartine (most exquisite orange hue), grossularite (brown, reddish brown, clear sparkling copper-gold to green), demantoid (unusual and rare among garnets and fancied for its brilliance and fire with refractive index 1.89. As a birthstone for those born in January, it symbolizes fidelity, friendship and constancy. It is reported from Hazara area, Lutkho valley Chitral [119]. Gem quality almandine (red garnet) is found in Chitral district. Tsavolite or green grossularite is associated with graphitic schist in Jambil area of Swat, near Kot in Malakand and near Targhao in Bajaur agency. Beautiful honey yellow euhedral crystals of hessonite are found in quartz mica schist near Targhao in Bajaur agency. Several showings of green garnet, serpentine and actinolite in Malakand and in lower Mohmand agency are reported [5].

Peridot: It belongs to olivine family. It is the birthstone for the month of $\mathrm{Au}$ gust and it is said to put ghosts and demons to flight, dispel melancholy and foolishness and to show the eternal paths to wisdom. It is found near the Kohistan-Kaghan watershed to the NE of Naran. It occurs along shear zones and in pockets in dunitic host rocks and are associated with clinochlore, magnetite and magnesite. It occurs in the immediate hanging wall of the Indus Suture. It 
represents the basal cumulates of the Sapat mafic-ultramafic complex [122] [135]. It is transparent to translucent and pale to dark yellowish green, rarely greenish yellow. It is medium to coarse grained with large crystals reported measuring more than $10 \mathrm{~cm}$ in length and upto $2 \mathrm{~kg}$ in weight. The reference [136] has presented physical data and microprobe analyses of the gem minerals. The Peridot is mostly $\mathrm{Fo}_{91}$ in composition but ranges from $\mathrm{Fo}_{90}$ to $\mathrm{Fo}_{94}$.

Corundum: Its gem varieties are ruby sapphire (red), oriental amethyst (blue), oriental emerald (green) and oriental topaz (yellow). It is found in the Timurgara Dir [137] and Shah Dheri and Kalam Swat [119].

Ruby: It belongs to corundum family and is popular due to the glowing red color. It is believed to symbolize that it endows children born in the month of July with priceless gifts, namely freedom, kindness, honor and dignity. Presently good quality ruby is a fairly rare gemstone and hence the most costly of all the precious stones. Ruby also occurs in a $30 \mathrm{~km}$ long belt of amphibolites extending from Timurgara in Khyber Pakhtunkhwa. The ruby of this area is lower grade. After Burma, the Hunza area is the only other region of the world that has produced blood red ruby. Cabochen grade violet or indigo colored sapphires also occur with rubies. The blood red rubies in present day gem market fetch the highest price. Thus there is great potential for development of ruby deposits in Pakistan. The host marble of this region also contains the minerals like sapphire, spinel, pargasite, margarite, phlogopite, chlorite, graphite, pyrite, rutile, dolomite, sphene, apatite, tourmaline, plagioclase, pyrrhotite, quartz, calcite, and goethite [120] [138].

Kyanite: Kyanite crystals are good and used as cheap gem. Detail in Kyanite in Industrial mineral.

Xenotime: It is $\mathrm{YPO}_{4}$; with REEs replacing Y. Xenotime is widespread accesory mineral in granite. It is misidentified with zircon. It is associated with zircon, monazite, allanite and other REEs. It is common detritial heavy mineral in sands and placer deposits. The Khyber Pakhtunkhwa Province has wide exposures of granite which may yield xenotime gemstones.

Topaz: It is fancied for its glowing, fiery sparkle and its wide range of colors ranging from yellow to golden brown, rose red to peach (Aro or Shuftalo) pink, blue to shining azure/sky blue and colorless to pure white. The yellow variety resemble citrine (yellow quartz), but it is more attractive mainly due to its higher refractive index (1.62), hardness 8 , and specific gravity 3.5 - 3.6. They mostly found in microcline-quartz-muscovite matrix. Topaz bearing pegmatites are found at Bulechi, Shingus and Gone near Dessu in the Skardu area. Pink Topaz is deep red to orange rose. In fact this is the only known naturally deep red or deep pink colored topaz in the world [139]. It is reported from Katlang Mardan [140], Lutkho valley Chitral [5]. The Katlang deposit [140] is located in the Gundao hillock $4 \mathrm{~km}$ north of the town of Katlang, about $20 \mathrm{~km}$ north of the city of Mardan, $60 \mathrm{~km} \mathrm{NE}$ of Peshawar. The Gandao hillock is comprised of grey, thin to thick bedded Paleozoic crystalline limestones. The limestone contains 
extensive stockworks of calcite and quartz veins which host the topaz mineralization. Pink topaz of Katlang is unique stone unparalleled in the world. It is found in Pakistan and if properly and correctly promoted in world market, its price can be very greatly enhanced [8].

Tourmaline: It is famous for its beautiful colors, occurring in all possible hues and shades. The more common hues are ruby red (rubellite), orange through brown to yellow, green and blue (indicolite). The gem varieties include rubellite, dravite, elbaite and liddicoatite [121]. It is believed to be stone for the October-born and is said to speed the writers' flow of thought [8]. It is reported from Lutkho valley Chitral [119] and Swat area [119]. Indicolite (blue tourmaline) is found in the pegmatites of Garm Chashma (Chitral). Some of the best and fairly large specimens of bicolor and tricolor tourmaline have been found in these pegmatites [134]. Several showings of black tourmaline in Malakand and lower Mohmand agency are also reported [5].

Bastnasite: Bastnasite $\left(\mathrm{CeLaCO}_{3} \mathrm{~F}\right.$-yellow brown hexagonal crystals)-a rare earth bearing gemstone reported in Zagai Ghar alkali granite-a part of Warsak alkaline granite crops out in the Peshawar plain [141].

Fluorite: Fluorite occurs near Mirgasht and Yarkhun in Trich valley, Chitral (Karakoram Block) and Chakdara (Dir; Himalayan crystalline zone) comprise fluorite quartz veins cutting mica granite gneiss which underlies a limestone and Bichoha Kurds near Sherwan, Hazara [142]. In Khyber-Hazara metasedimentary fold and thrust belt fluorite occurs as disseminations in silicic dykes cutting schists of Hazara Formation [143].

\subsection{Gemstone and Jewelry Resources from Gilgit Baltistan, Pakistan}

The reference [144] provided the first information about the gemstones from Gilgit Baltistan. The Gilgit Baltistan province is very significant for gemstone resources because of hosting two main sutures like northern Indus and Karakoram (Shyok Suture). The high temperature created by geodynamics and tectonic collision of Indo-Pak subcontinent, so their sutures are producing gemstones and also significant for further exploration.

Gold-Silver-Platinum: The reference [123] [124] reported alluvial gold and mineral in Gilgit-Baltistan areas. In Northern areas under Gold Exploration and Mineral Assessment Project (GEMAP), carried by Australian Assistance during 1992-95, the integrated sampling and geochemical maps were prepared. Gold was detected in many hundreds of drainage cells (tributaries). Among these 24 sites shows high anomalous gold. These anomalies are mostly associated with major shear zone/Indus Suture and some are porphyry type intrusives or altered carbonates [125]. The upper reaches of Chitral, Gilgit and the Indus River in northern parts of Pakistan are well known for the placer gold occurrences [126]. The Bagrot valley [127], Shigari Bala area of Skardu [128] and Golo Das and surrounding areas [129] of Gilgit-Baltistan seems to be significant for gold and 
base metal mineralizations.

Aquamarine: It is reported from Dassu and Khaplu, Baltistan [5]. It occurs in the pegmatites of Karakoram and NW Himalayas. Light blue aquamarine is most abundant in the gem pegmatites of Gilgit-Skardu area [121]. The better known deposits are Iskere, Shingus, Dusso and Tisgtung. These areas have good potential for deeper blue colour, high priced aquamarine and merits further exploration and development.

Emerald: It is found in ophiolitic rocks of mélange zone of northern Indus Suture. The emerald deposits occur at near Khaltaro in Gilgit area [145]. In short it has great potential for enhancing emerald production and mining activities.

Fluorite: The fluorite $\left(\mathrm{CaF}_{2}\right)$ mineralization is found in the Karakoram and Indus suture and adjoining zones associated with other gemstones.

Xenotime: It is $\mathrm{YPO}_{4}$; with REEs replacing Y. Xenotime is widespread accesory mineral in granite. It is misidentified with zircon. It is associated with zircon, monazite, allanite and other REEs. It is common detritial heavy mineral in sands and placer deposits. The Gilgit Baltistan regions have wide exposures of granite which may yield xenotime gemstones.

Garnet: It is reported from Bash-Shigar and Khaplu Baltistan [5] and Harmosh range Gilgit [119]. Gem quality red spessartine is associated with pegmatites of Dusso and Shingus in northern areas. This deposit has yielded large transparent crystals [8].

Moonstone: It has been mined from pegmatites of Shingus and Bulechi in Gilgit Agency. The deposits are large with good quality. The adularia feldspar is called sunstone.

Pargasite: It belongs to monoclinic amphibole. Exquisite deep pistachio green crystals of pargasite occurred in metamorphosed crystalline marbles along with ruby and spinel in the Hunza valley. It is translucent to opaque and used into beautiful cabochons. Locally they are sold as Hunza emeralds.

Quartz Crystals and Jewelry: Quartz crystals are found in pegmatites and suture areas. These crystals can be used in best jewelry for attraction as diamond because India is famous due to using diamond in jewelry. Pakistan has many quartz crystals deposits. For detail, see in quartz veins title. It is used as gem and also used for dishes, optical instruments, spectacles, chemical, radio appliances, frequency control in electrical and radio apparatus. It is silicon dioxide and common rock mineral and also includes a number of ornamental varieties. The ornamental varieties can be crystalline such as amethyst and citrine or cryptocrystalline such as opal, agate, chrysoprase, chalcedony, and cornelion. The violet quartz or amethyst is the birthstone for the February born and to symbolize durability, friendship and stead fastness in love. Clear and well formed crystals of quartz occur in gem pegmatite in Skardu and Gilgit areas. Smoky quartz occurs in these areas also. Rose quartz is abundant is Dusso pegmatites near Skardu.

Corundum: Its gem varieties are ruby sapphire (red), oriental amethyst 
(blue), oriental emerald (green) and oriental topaz (yellow). It is found in the suture and vicinity areas.

Ruby: It is reported from the marble of Bashe-Highar and Strakin Rondu, Baltistan [5]. The main deposits occur in the dolomitic marble extending for over $100 \mathrm{~km}$ from Hunza valley to Ishkoman, close to Main Karakoram Thrust. Mining is confined to 13 mining centers spread over a length of $15 \mathrm{~km}$ in Hunza Valley. Ruby may be found in Astore region. Thus there is great potential for development of ruby deposits in Pakistan. The host marble of this region also contains the minerals like sapphire, spinel, pargasite, margarite, phlogopite, chlorite, graphite, pyrite, rutile, dolomite, sphene, apatite, tourmaline, plagioclase, pyrrhotite, quartz, calcite, and goethite [120] [138] [139].

Sapphire: It is found in the Illaga Khorming Baltistan [5].

Spinel: It is a group with magnesium aluminium oxide composition. It is admired for its lovely vibrant colors, strong brilliance, and striking clarity. It can be withstand great heat without change and occurs in an extremely beautiful variety. Purple to blue and blue green varieties are also common. Spinal with its ruby red colour is closely associated with Hunza ruby deposits [146]. The red colour of spinel is due to presence of chromium, where as the bluish and plum (Alu Bukhara) colored varieties owe their colour to the presence of iron [121]. The Hunza spinels are larger than those customarily found in Burma and are far more attractive.

Topaz: It is fancied for its glowing, fiery sparkle and its wide range of colors ranging from yellow to golden brown, rose red to peach (Aro or Shuftalo) pink, blue to shining azure/sky blue and colorless to pure white. The yellow variety resemble citrine (yellow quartz), but it is more attractive mainly due to its higher refractive index (1.62), hardness 8 , and specific gravity 3.5 - 3.6. They mostly found in microcline-quartz-muscovite matrix. Topaz bearing pegmatites are found at Bulechi, Shingus and Gone near Dessu in the Skardu area. It is reported from Harmosh range, Iskere valley Gilgit [119]. It is found in Pakistan and if properly and correctly promoted in world market, its price can be very greatly enhanced [8].

Tourmaline: The gem varieties include rubellite, dravite, elbaite and liddicoatite [121]. It is believed to be stone for the October-born and is said to speed the writers' flow of thought. It is reported from Khaplu Baltistan [5], Harmosh range [119]. It is found in the pegmatites of the Haramosh range near Gilgit, Stak Nala (Between Gilgit and Skardu), Bulechi and Shingus (Gilgit Division). Some of the best and fairly large specimens of bicolor and tricolor tourmaline have been found in these pegmatites [134].

Pegmatite gems and other Mineral Specimen: The pegmatites from northern areas have yielded excellent specimens like light pink crystals of fluorapatite, fluorite, green microcline, aquamarine, tourmaline, topaz, garnet, spessartine, hambergite, morganite (rose coloured variety of beryl), goshenite, epidote, quartz [147]. Black Tourmaline/schorl is ubiquitous in entire gem localities of 
northern areas [148]. Beautiful pyrite, malachite, and azurite specimens can be collected near Gilgit. The reference [149] reported some other gemstones from Pakistan like agate, actinolite, amazonite (feldspar/microcline), azurite, epidote, jadeite (nephrite is a jade), kunzite (transparent variety of spodumene pyroxene), margarite (the mineral of hydrated silicate of $\mathrm{Ca}$ and $\mathrm{Mg}$; with pearly luster), pargasite (hornblende), rutile, serpentine, turquoise (phosphate minerals), sapphire (blue variety of tourmaline), lapis lazuli (lazurite, feldspathoid group), tripoli (weathered chert/siliceous limestone), etc.

\subsection{Gemstone and Jewelry Resources from Azad Kashmir, Pakistan}

Azad Kashmir is producing following gemstones and jewelry resources.

Gold-Silver-Platinum: Gold is found from Shontar and Shardi Nala and other places of upper reaches of Neelam River in Azad Kashmir. The Neelam valley is significant for primary/in situ gold exploration. However as placer deposits the Neelam and Jhelum rivers and their tributaries are significant.

Garnet: A high quality orange red spessartine garnet has been recently discovered in pegmatites in Jandran Wala, Neelam valley of Azad Kashmir. This deposit has yielded large transparent crystals [8].

Ruby: Ruby deposits of Azad Kashmir are located in Khandigali-NangimaliKhora-Katha, Chitta Ratta, Kalajandar and Naril Nala areas of Neelam valley. They are associated with marbles, meta limestone and occur in calcite veins along bedding planes. The deposits are being mined and the reserves are estimated at about 24.9 million grams [150]. The ruby quality is excellent where phlogopite, fuchsite, chrom diopside, calcite and minor pyrite and muscovite are present. The size of light pink ruby crystal increases where graphite, pyrite and phlogopite are present with minor fuchsite. The gemological and mineralogical characters of Kashmir metamorphic ruby are very similar to Bermese ruby [151].

Sapphire: It is found in the Mochel, Padror Azad Kashmir [5].

Xenotime: It is $\mathrm{YPO}_{4}$; with REEs replacing Y. Xenotime is widespread accesory mineral in granite. It is misidentified with zircon. It is associated with zircon, monazite, allanite and other REEs. It is common detritial heavy mineral in sands and placer deposits. The Neelam and Reshian valleys of Azad Kashmir have wide exposures of granite which may yield xenotime gemstones.

Tourmaline: Green tourmaline/Indicolite and rubellite has been found in pegmatites of Donga Nar in Azad Kashmir. Some of the best and fairly large specimens of bicolor and tricolor tourmaline reported from pegmatites [134]. The black tourmaline/schorl associated with garnet and quartz from Jandran Wala area.

Quartz Crystals and Jewelry: Clear and well formed crystals of quartz occur in gem pegmatite in Jandran Wala, Neelam valley, Azad Kashmir areas. Smoky and rose quartz occurs in these areas also.

Pegmatite: The pegmatites from upper Neelam areas have yielded excellent 
gemstone specimens. Aquamarine, beryl and topaz and many other gemstones from Gurais and Donga Nar found in pegmatites.

\subsection{Gemstone and Jewelry Resources from Balochistan Province, Pakistan}

The Balochistan basin represents gemstones like well developed quartz crystals, fluorite, chalcedony (chert, jasper, flint, agate, amethyst, etc.), almandine garnet, tsavorite garnet, actinolite, natrolite/zeolite, marble, malachite, azurite, chrysocolla, epidote, rodingite (formed by rodingitization process-which are metasomatised calc-silicate rocks associated with serpentinites), calcite, etc. [9]. The reference [152] also reported many gemstones from Muslimbagh area of Balochistan like natrolite, marble, serpentine, talc, quartz, chert, green chert, calcite, agate, amethyst, copper minerals (malachite, azurite, chrysocolla), jasper, flint, agate, amethyst, etc), almandine garnet, tsavorite garnet, actinolite, epidote.

Gold-Silver-Platinum: Chagai district has a number of porphyry copper deposits with gold and silver mineralizations [153]. Broken Hill Propriety (BHP) of Australia in collaboration with BDA has discovered world class gold deposits. Lake Resources (Australia) also explored copper and associated gold deposits and their alteration zones. Muslimbagh area show platinum group elements (PGE) associated with chromitites in the Muslimbagh ophiolites of Saplai Tor Ghar. Preliminary study show the primary deposits but not economic and however there are chances of economic placer deposits (Nakagawa et al., 1996). The two samples from tectonites show ppb values of Os 24, 36; Ir 30, 45; Ru 85, 130; Rh 10, 13.3; Pt 35, 33; Pd 15, 46; Au 2.5, 7.4; Total PGE 179, 303 The three samples from cumulate show ppb values of Os 41, 13, 6; Ir 35, 24, 7.7; Ru 100, 55, 9; Rh 16.8, 11.1, 4.5; Pt <5, <5, 18; Pd 4, 3, <2; Au 9.1, 7.4, 1.3; Total PGE 202, 111, 47; CI-chondrite value of OS 514, Ir 540, Ru 690, Rh 200, Pt 1020, and Pd 545. The reference [14] reported 2 samples of main Siahgari Shand quartz vein (35A/11) show Ag 4 ppm and $\mathrm{Au} 0.45-0.48 \mathrm{ppm}$ and 8 samples from Eastern Waro $(35 \mathrm{M} / 16)$ show Ag $<2$ ppm, Au BDL and Mercury $39-115$ ppb. The reference [14] reported antimony and red to brown iron oxide veins of Siahan and north Makran show some gold and silver mineralization. 25 samples from Safed Gilanchi (31M/15) show Au 0.04 - 4.4 ppm, 9 samples from Mir Baig Raidki (31M/15) show Au from BDL-2.14 ppm, 8 samples from Machi Koh (31M/15) show Au BDL-4.49 ppm and Ag 0.38 - 4.32 ppm, 13 samples from Palantak Koh (35A/2) show $\mathrm{Au} 0.005$ - $1.298 \mathrm{ppm}, 3$ samples from Jauder (35A/11) show $\mathrm{Au}$ 0.03 - 8.35ppm and Ag 2 - 4 ppm, 1 sample from Gokumb north (35A/11) shows Au $1.7 \mathrm{ppm}$ and Ag $2 \mathrm{ppm}, 1$ sample from Hurain (35A/11) shows Au $8.81 \mathrm{ppm}$ and Ag $4 \mathrm{ppm}, 1$ sample from Surmagi south (35A/11) shows $\mathrm{Au} 0.5 \mathrm{ppm}$ and Ag 4 ppm, 1 sample from Huspi (35A/11) shows Au 0.16 ppm and Ag 5 ppm, 2 samples from Siahgari (35A/11) show Au 0.10 - 0.24 ppm and Ag 4 - 7 ppm, 1 sample from Kuchaki south (35A/11) shows Au 0.12 ppm and Ag 6 ppm, 1 sample from Kuchaki north show Au 0.13 ppm and Ag 2 ppm, 1 sample from Go- 
kumb south (35A/11) shows Au $0.05 \mathrm{ppm}$ and Ag $6 \mathrm{ppm}, 1$ sample from Ahmadap (35A/11) shows Au 0.63 ppm and Ag 5 ppm, 2 samples from Mahmoodi Kaur (35A/11) show Au $0.05-0.07$ ppm and Ag 4 - 5 pp, 2 samples from Kasig (35A/11) show Au $0.26-0.28 \mathrm{ppm}$ and Ag 4 ppm, 1 sample from Panir Body east (35A/11) shows Au BDL and Ag 3 ppm, 2 samples from Sor Jor Jauder (35A/11) show Au BDL-0.48 ppm and Ag 3 - 5 ppm, 1 sample from Nagindap Damagi (35A/11) shows Au $0.78 \mathrm{ppm}$ and Ag BDL, 2 samples from Musa Kaur (35A/11) show Au $0.05-0.06 \mathrm{ppm}$ and Ag 5 pp and 1 sample from Hashani (35A/11) shows Au $1.28 \mathrm{ppm}$ and Ag 2 ppm. 4 samples from Surap (35A/6) show Au BDL-0.03 ppm and Ag 0.73 - 1.84 ppm, 1 sample from Gumtalan $(31 \mathrm{M} / 11)$ shows $\mathrm{Au} 0.02 \mathrm{ppm}$ and $\mathrm{Ag} 0.97 \mathrm{ppm}, 1$ sample from Baskroach (31M/11) shows Au $0.03 \mathrm{ppm}$ and $\mathrm{Ag} 01.59 \mathrm{ppm}, 1$ sample from Kashi (31M/11) shows Au $0.03 \mathrm{ppm}$ and Ag $1.05 \mathrm{ppm}, 1$ sample from Patangaz (31M/11) shows $\mathrm{Au} 0.01 \mathrm{ppm}$ and Ag $1.36 \mathrm{ppm}, 1$ sample from Wazhdad (35A/6) shows Au 0.02 ppm and Ag 0.95 ppm, 1 sample from Siah Mar (31M/12) shows Au $0.02 \mathrm{ppm}$ and $\mathrm{Ag} 1.19 \mathrm{ppm}$ and 1 sample from Sorgari $(31 \mathrm{M} / 16)$ shows $\mathrm{Au} 0.01 \mathrm{ppm}$ and Ag 0.86 ppm. 1 sample from Panjgur area (35B/1) show $0.31 \mathrm{ppm}$ and $\mathrm{Ag} 2.12$ ppm, 1 sample from Sabzab (35A/12) shows Au 0.04 ppm and Ag 2.12 ppm, 1 sample from Saghar (35A/4) shows Au $0.12 \mathrm{ppm}$ and $\mathrm{Ag} 2.13 \mathrm{ppm}$ and 1 sample from Thalo Thalaran (31M/16) shows Au $0.03 \mathrm{ppm}$ and Ag $1.72 \mathrm{ppm} .62 \mathrm{sam}-$ ples of iron oxidized (brown-red) rocks of Makran and Siahan ranges show $\mathrm{Au}$ BDL and $\mathrm{Ag}<2$ - 7 ppm [19].

Fluorite: It is used as a flux in making steel, in the manufacture of white and coloured opalescent glass, in enameling cooking utensils, for the preparation of Hydrofluoric acid and elemental fluorine and also as ornamental use. The main fluorite $\left(\mathrm{CaF}_{2}\right)$ deposits are found in the Dilband range (Figure 3), Mula-Zahri range (Figure 3), and Loralai ranges (Figure 3) of Balochistan. Trivial showings occur in the Zhob ophiolite at Brunj Killi and Khojakzai where fluorite-calcite vein cut the Triassic Wulgai Formation [4] [143]. The first largest deposits of fluorite from Pakistan are located in Dilband and its vicinity areas of Kirthar foldbelt. The Koh Maran fluorite (72 long tons) was reported by [154]. Dilband-Maran fluorite is found as calcite-fluorite veins in Jurassic Chiltan limestone. The reference [155] estimated 95,000 ton ore containing 50\% fluorite. The reference [156] estimated over $0.1 \mathrm{mt}$ of fluorite from Dilband and its vicinity areas. The reference [49] [50] discovered the second largest deposits (6750 tons) of green fluorite veins in Jurassic Chiltan limestone from Mula-Zahri Range of Kirthar foldbelt. The reference [14] [19] [51] discovered the third largest deposits of fluorite from Loralai district of Sulaiman Foldbelt. It is found in Gadebar and Daman Ghar ranges and associated domes and long hillocks of Jurassic Loralai limestone forming anticlinal cores. The fluorite occurs as veins in faults and fractures and enriched particularly in the low dip strata. The fluorite represents many colour like pink, blue, light grey, green, light yellow, etc. It may contain $\mathrm{CaF}_{2} 80 \%-90 \%$. The fluorite seems to be good for acid preparation, metallur- 
gical grades and gemstones. The present investigations show that the Jurassic strata of Sulaiman foldbelt have possible largest deposits in Pakistan. The fluorite shows impurities as calcite and quartz in the area. Now, it is being mined from Loralai district areas where tribal disputes are not found but most of the fluorite host areas are in dispute and needs fruitful agreements between tribes to exploit fluorite. Mining is in progress in the Mekhtar (Balao, Inde, Sande and Zhizhghi), Tor Thana and Zarah areas. The estimated reserves are about 50,000 tons. Attractive fluorite crystals for gem with light green, yellow and light blue colors from Mekhtar, Wategam Zarah etc of Loralai district have also been found. It is also interpreted that the Jurassic limestone of Kirthar and Sulaiman foldbelts and adjoining Western Indus Suture Zone seems to be significant for further prospecting especially in the low dip strata.

Chert, Jasper, Flintstone, Quartz Crystals for Jewelry: As Mari Indus quartz crystals are known as Mari Diamond found in Salt range formation near the Mari Indus close to Kalabagh (Ahmad 1969). These crystals can be used in best jewelry for attraction as diamond because India is famous due to using diamond in jewelry. Pakistan has many quartz crystals deposits. For detail, see in quartz veins title. It is used as gem and also used for dishes, optical instruments, spectacles, chemical, radio appliances, frequency control in electrical and radio apparatus. It is silicon dioxide and common rock mineral and also includes a number of ornamental varieties. The ornamental varieties can be crystalline such as amethyst and citrine or cryptocrystalline such as opal, agate, chrysoprase, chalcedony, and cornelion. The violet quartz or amethyst is the birthstone for the February born and to symbolize durability, friendship and stead fastness in love. Clear and well formed crystals of quartz occur in gem pegmatite in Skardu, Gilgit and Chitral areas, and in Azad Kashmir. Smoky quartz occurs in these areas also. Rose quartz is abundant is Dusso pegmatites near Skardu. Agate and chalcedony are found in near Nagar Parker Sindh, while jasper occurs in Las Bela area (Balochistan). The reference [14] [19] reported quartz veins having white transparent to translucent quartz crystals which are found in the sandstone of Cretaceous Mughalkot formation in the Khagoon (39F/10) of Gharwandi (Alu Khan Kach) area. He also reported flint or flintstone from Tor Thana (39F/3) of Loralai district in Late Cretaceous Mughalkot formation (shale, sandstone and limestone), which show banded and wavy white and light blue colors which creates beauty for ornamental purposes. The beautiful chert and jasper beds are also found in the peaks of Jurassic limestone west and southwest of Khad Kucha, Mastung district, and also found in the Jurassic and Cretaceous limestone in Loralai and Mekhtar area. So far flint stone is being produced from Sindh. The reference [14] [17] reported quartz crystal from quartz vein of Shand and Waro area of Siahan range.

Calcite: The beautiful calcite and calcite veins are commonly found in the limestone of different ages especially the Mastung, Kalat, Khuzdar, Quetta, Ziarat, Loralai and vicinity regions. 
Garnet and Tourmaline: These are known from Chagai and Muslimbagh area.

Vesuvianite/Idocrase: Idocrase/Vesuvianite is reported in Muslimbagh area in ophiolitic rocks [5].

Copper minerals as gemstones: The copper minerals like malachite, azurite, chrysocolla, chalcopyrite, etc are known from Chagai, Raskoh, Western Indus Suture (WIS; Lasbela-Khuzdar-Muslimbagh-Zhob) and sedimentary belts (Pab sandstone in Kharzan, Mula-Zahri range, etc).

Pegmatite gems and other mineral specimen: The pegmatites are also reported from Chagai and Tor Ghundi (Loralai) areas. The Tor Ghundi pegmatite is a pipe type (low in silica) intruded in the Early Cretaceous Parh Group [79]. These may reveal gemstones. Tor Ghundi pegmatite is low in silica may host very significant gemstones and other economic minerals. It needs detail work.

\subsection{Gemstone and Jewelry Resources from North Punjab Province, Pakistan}

Gold-Silver-Platinum: Kirana group (Sargodha District) shows traces of gold from volcanogenic hematite iron ore near Chiniot [157]. The Precambrian Indo-Pakistan shield rocks of Kirana group are also significant for gold [8]. The explorations for Placer gold in Indus river deposits are significant.

Mari Diamond (Quartz): The best quartz crystals from Mari area near to Kalabagh for gem are called Mari diamond (quartz) which can be used in jewelry as diamond.

Amorphous Silica and beautiful pebbles and cobbles: The chalcedonic silica like Chert, flint, jasper, etc, along with other significant and beautiful pebbles and cobbles found as detritial/placer in the conglomerate and conglomeratic sandstone/gritstone in the Miocene-Pliocene Potwar Group and also in the Pleistocene-Holocene Soan Group in the Potwar sub-basin.

\subsection{Gemstone and Jewelry Resources from South Punjab (Saraikisan/Saraiki Province), Pakistan (Sulaiman Basin or Middle Indus Basin)}

Gold-Silver-Platinum: Indus river placer is very significant for gold and heavy mineral panning and stream sediments washing and further exploration in adjoining Late Tertiary and Pleistocene alluvial deposits and recent eolian deposits.

Amorphous Silica and beautiful pebbles and cobbles: The chalcedonic silica like Chert, flint, jasper, etc, along with other significant and beautiful pebbles and cobbles are found as detritial/placer in the conglomerate and conglomeratic sandstone/gritstone are found in the Oligocene-Pliocene Vihowa Group and also in the Pleistocene-Holocene Sakhi Sarwar Group in the Sulaiman foldbelt. These are significant for jewelry resources as found relatively easy.

Gemstones Resources from Placer deposits: Primarily the gemstones are hosted in bed rocks [158] [159] [160]. Due to tectonic and geodynamics and northward movement of Indo-Pakistan plate from southern hemisphere (Gond- 
wana) toward Asia during Cretaceous, the collision with Asia at end Cretaceous, resulted the uplift of northern Indus suture and western Indus suture zones. This uplift closed the Tethys and created the Paleo Indus River systems which deposited the alluvial deposits carrying minerals from primary rocks. This is the reason the placer deposits are significant for exploration of gemstones, gold, REEs, and other heavy minerals. The worker may be encouraged for stream sediments, alluvial and placer washing methods, alluvial for collection of gold, gemstones, REEs and heavy minerals like monazite, zircon, rutile, ilmenite, etc.

\subsection{Gemstone and Jewelry Resources from Sindh Provinces, Pakistan}

Gemstones like agate and chalcedony from Nagar Parker, chert, flint and Jasper from Vihowa group/Manchar group especially from the conglomerate, gritstone, conglomeratic sandstone of Manchar/Vihowa group of eastern Kirthar and Lakhi range and other areas. So far flint stone is being produced from Sindh Province.

\section{Conclusions}

Pakistan has large number of cement resources, agrominerals, marble, construction, dimension and décor stone resources, gemstone and jewelry resources for sustainable exploitation and developments of the different provinces and regions especially poorly developed South Punjab (Saraikistan/Saraiki Province), Balochistan and other remote regions. The installation of cement industries especially in South Punjab/Saraikistan and eastern Balochistan due to its central location in Pakistan, close to CPEC route and also close occurrences of raw materials like gypsum, limestones and shales at one place develop the area and increase the export. The Koh Sulaiman regions of South Punjab (Saraikistan) have huge gypsum deposits which deserve for further exploitation and export. Pakistan is agricultural country and fertility of cultivated lands is vital. Pakistan has very large construction, dimension and decor stone deposits like limestone, marble, dolomite and igneous rocks like granite, dolerite, serpentine, etc. which needs further exploitation for the development of the areas and increase export. To increase gems and jewelry export, these industries require reduction in gemstones smuggling and encouragement for gem appraisal and jewelry industry at high level for value addition. In short, Pakistan is rich in minerals and try should be made to develop and export the own mineral commodities like cement, gypsum, marble, gemstones and jewelry.

\section{Conflicts of Interest}

The author declares no conflicts of interest regarding publication of this paper.

\section{References}

[1] Jan, M.Q. and Gauhar, S.H. (2013) Earth Sciences and Mineral Exploration History 
of Pakistan with Reference to Khyber Pakhtunkhwa and Its Adjacent Tribal Areas. Abstract Volume, Sustainable Utilization of Natural Resources of the Khyber Pakhtunkhwa and FATA, February 11, Peshawar, Pakistan. Journal of Himalayan Earth Sciences, 2013, 15-16.

[2] Gee, E.R. (1949) Mineral Resources of North West India. Geological Survey of Pakistan, Record, Vol. 1, 1-25.

[3] Heron, A.M. (1950) Directory of Economic Minerals. Geological Survey of Pakistan, Record, Vol. 1, 1-69.

[4] Heron, A.M. and Crookshank, H. (1954) Directory of Economic Minerals of Pakistan. Geological Survey of Pakistan, Record, Vol. 7, 1-146.

[5] Ahmad, Z. (1969) Directory of Mineral Deposits of Pakistan. Geological Survey of Pakistan, Record, Vol. 15, 1-200.

[6] Gauher, S.H. (1969) Economic Minerals of Pakistan: A Brief Review. Geological Survey of Pakistan, Pre Publication Issue 88, 1-110.

[7] Ahmad, Z. and Siddiqui, R.A. (1992) Mineral and Rocks for Industry. Geological Survey of Pakistan, Quetta, 325 p.

[8] Kazmi, A.H. and Abbas, S.G. (2001) Metallogeney and Mineral Deposits of Pakistan. Orient Petroleum Incorporation, Islamabad, Graphic Publishers, Karachi, 264 p.

[9] Malkani, M.S. and Mahmood, Z. (2016) Mineral Resources of Pakistan: A Review. Geological Survey of Pakistan, Record, Vol. 128, 1-90.

[10] Malkani, M.S. and Mahmood, Z. (2017) Mineral Resources of Pakistan: Provinces and Basins Wise. Geological Survey of Pakistan, Memoir, Vol. 25, 1-179.

[11] Malkani, M.S., Alyani, M.I., Khosa, M.H. Somro, N., Arif, S.J., Tariq, S., Saeed, F., Khan, G. and Faiz, J. (2016) Mineral Resources of Pakistan-An Update. Lasbela University Journal of Science and Technology, 5, 90-114.

[12] Jones, A.G., Manistere, B.E., Oliver, R.L., Willson, G.S. and Scott, H.S. (1961) Reconnaissance Geology of Part of West Pakistan. Colombo Plan Co-Operative Project Conducted and Compiled by Hunting Survey Corporation, Government of Canada, Toronto, $550 \mathrm{p}$.

[13] Ahmad, Z. (1975) Directory of Mineral Deposits of Balochistan. Geological Survey of Pakistan, Record, Vol. 36, 1-178.

[14] Malkani, M.S. (2011) Stratigraphy, Mineral Potential, Geological History and Paleobiogeography of Balochistan Province, Pakistan. Sindh University Research Journal (Science Series), 43, 269-290.

[15] Malkani, M.S., Mahmood, Z., Shaikh, S.I. and Arif, S.J. (2017) Mineral Resources of Balochistan Province, Pakistan. Geological Survey of Pakistan, Information Release, No. 1001, 1-43.

[16] Malkani, M.S. (2004) Mineral Potential of Siahan and North Makran Ranges, Balochistan, Pakistan. Abstract Volume National Conference on Economic and Environmental Sustainability of Mineral Resources of Pakistan, Baragali, 20-22 July 2004, 46-47.

[17] Malkani, M.S. (2004) Stratigraphy and Economic Potential of Sulaiman, Kirthar and Makran-Siahan Ranges, Pakistan. Fifth Pakistan Geological Congress, Islamabad, 14-15 April 2004, 63-66.

[18] Malkani, M.S., Mahmood, Z., Arif, S.J. and Alyani, M.I. (2017) Revised Stratigraphy and Mineral Resources of Balochistan Basin, Pakistan. Geological Survey of Pakis- 
tan, Information Release, No. 1002, 1-38.

[19] Malkani, M.S. (2010) Updated Stratigraphy and Mineral Potential of Sulaiman (Middle Indus) Basin, Pakistan. Sindh University Research Journal (Science Series), 42, 39-66.

[20] Malkani, M.S., Mahmood, Z., Alyani, M.I. and Shaikh, S.I. (2017) Revised Stratigraphy and Mineral Resources of Sulaiman Basin, Pakistan. Geological Survey of Pakistan, Information Release, No. 1003, 1-63.

[21] Malkani, M.S., Mahmood, Z., Somro, N. and Shaikh, S.I. (2017) Revised Stratigraphy and Mineral Resources of Kirthar Basin, Pakistan. Geological Survey of Pakistan, Information Release, No. 1010, 1-59.

[22] Malkani, M.S., Khosa, M.H., Alyani, M.I., Somro, N., Zafar, T., Arif, J. and Aleem, M.Z. (2017) Revised Stratigraphic Setup and Mineral Deposits of Kirthar Basin (Lower Indus Basin), Pakistan. Lasbela University Journal of Science and Technol$o g y, 6,54-84$.

[23] Malkani, M.S. (2020) Revised Stratigraphy and Mineral Resources of Balochisatan Basin, Pakistan: An Update. Open Journal of Geology, 10, 784-828. https://doi.org/10.4236/ojg.2020.107036

[24] Malkani, M.S., Mahmood, Z., Somro, N. and Alyani, M.I. (2017) Cement Resources, Agrominerals, Marble, Construction, Dimension and Decorative Stone Resources of Pakistan. Geological Survey of Pakistan, Information Release, No. 1005, 1-23.

[25] Malkani, M.S., Mahmood, Z., Somro, N. and Arif, S.J. (2017) Gemstone and Jewelry Resources of Pakistan. Geological Survey of Pakistan, Information Release, No. 1004, 1-28.

[26] Malkani, M.S., Mahmood, Z., Alyani, M.I. and Siraj, M. (2017) Mineral Resources of Khyber Pakhtunkhwa and FATA, Pakistan. Geological Survey of Pakistan, Information Release, No. 996, 1-61.

[27] Malkani, M.S., Khosa, M.H., Alyani, M.I., Khan, K., Somro, N., Zafar, T., Arif, J. and Zahid, M.A. (2017) Mineral Deposits of Khyber Pakhtunkhwa and FATA, Pakistan. Lasbela University Journal of Science and Technology, 6, 23-46.

[28] Malkani, M.S. and Mahmood, Z. (2016) Mineral Resources of Azad Kashmir and Hazara (Pakistan): Special Emphasis on Bagnotar-Kala Pani (Abbottabad, Hazara) New Coalfield. Abstract Volume, Earth Sciences Pakistan 2016, 15-17 July, Baragali Summer Campus, University of Peshawar, Pakistan. Journal of Himalayan Earth Sciences, 2016, 103.

[29] Malkani, M.S., Shah, M.R., Sajjad, A., Kakepoto, A.A. and Haroon, Y. (2013) Mineral and Gemstone Resources of Northern Khyber Pakhtunkhwa and FATA Regions, Pakistan-A Good Hope. Abstract Volume, Sustainable Utilization of Natural Resources of the Khyber Pakhtunkhwa and FATA, February 11, Peshawar, Pakistan. Journal of Himalayan Earth Sciences, 2013, 25-26.

[30] Malkani, M.S. (2013) Natural Resources of Southern Khyber Pakhtunkhwa and FATA Regions (Kohat Sub-Basin and Part of Northern Sulaiman Basin and Western Indus Suture), Pakistan-A Review. Abstract Volume, Sustainable Utilization of Natural Resources of the Khyber Pakhtunkhwa and FATA, February 11, Peshawar, Pakistan. Journal of Himalayan Earth Sciences, 2013, 30-31.

[31] Malkani, M.S. (2012) Natural Resources of Khyber Pakhtunkhwa, Gilgit-Baltistan and Azad Kashmir, Pakistan. In, Abstract Volume, Earth Sciences Pakistan 2012, June 23-24, Baragali Summer Campus, University of Peshawar, Pakistan. Journal of Himalayan Earth Sciences, 45, 70. 
[32] Malkani, M.S., Mahmood, Z., Shaikh, S.I. and Alyani, M.I. (2017) Mineral Resources of North and South Punjab, Pakistan. Geological Survey of Pakistan, Information Release, No. 995, 1-52.

[33] Malkani, M.S. (2012) A Review on the Mineral and Coal Resources of Northern and Southern Punjab, Pakistan. In, Abstract Volume, Earth Sciences Pakistan 2012, June 23-24, Baragali Summer Campus, University of Peshawar, Pakistan. Journal of Himalayan Earth Sciences, 45, 67.

[34] Malkani, M.S., Mahmood, Z., Alyani, M.I. and Shaikh, S.I. (2017) Mineral Resources of Sindh, Pakistan. Geological Survey of Pakistan, Information Release, No. 994, 1-38.

[35] Malkani, M.S. (2014) Mineral Resources of Sindh Province, Pakistan. In, Abstract Volume, Earth Sciences Pakistan 2014, August 29-31, Baragali Summer Campus, University of Peshawar, Pakistan. Journal of Himalayan Earth Sciences, 2014, 57-58.

[36] Malkani, M.S., Mahmood, Z., Usmani, N.A. and Siraj, M. (2017) Mineral Resources of Azad Kashmir and Gilgit Baltistan, Pakistan. Geological Survey of Pakistan, Information Release, No. 997, 1-40.

[37] Malkani, M.S. (2014) Mineral and Gemstone Resources of Azad Kashmir and Gilgit-Baltistan (Pakistan). In, Abstract Volume, Earth Sciences Pakistan 2014, August 29-31, Baragali Summer Campus, University of Peshawar, Pakistan. Journal of Himalayan Earth Sciences, 2014, 58-59.

[38] Malkani, M.S. (2020) Mineral Resources of Gilgit Baltistan and Azad Kashmir, Pakistan: An Update. Open Journal of Geology, 10, 661-702. https://doi.org/10.4236/ojg.2020.106030

[39] Malkani, M.S. and Mahmood, Z. (2016) Revised Stratigraphy of Pakistan. Geological Survey of Pakistan, Record, Vol. 127, 1-87.

[40] Malkani, M.S. and Mahmood, Z. (2017) Stratigraphy of Pakistan. Geological Survey of Pakistan, Memoir, Vol. 24, 1-134.

[41] Malkani, M.S., Alyani, M.I., Khosa, M.H., Saeed, F., Haroon, A., Buzdar, M.A. and Kakar, A.S. (2015) Revised Stratigraphy of Indus and Balochistan Basins (Pakistan): Sea Level Changes and Land-Ocean Connections of Mesozoic and Cenozoic Strata. Lasbela University Journal of Science and Technology, 4, 21-27.

[42] Malkani, M.S. (2016) Revised Stratigraphy of Indus Basin (Pakistan): Sea Level Changes. Pages 96-99. In Book ISBN 978-5-4262-0073-9. In: Dzyuba, O.S., Pestchevitskaya, E.B. and Shurygin, B.N., Eds., Cretaceous Ecosystems and Their Responses to Paleoenvironmental Changes in Asia and the Western Pacific, Trofimuk Institute of Petroleum Geology and Geophysics, Siberian Branch, Russian Academy of Science (IPGG SB RAS), Novosibirsk, 96-99.

[43] Malkani, M.S. (2012) Revised Lithostratigraphy of Sulaiman and Kirthar Basins, Pakistan. In, Abstract Volume, Earth Sciences Pakistan 2012, June 23-24, Baragali Summer Campus, University of Peshawar, Pakistan. Journal of Himalayan Earth Sciences, 45, 72.

[44] Malkani, M.S., Shahzad, A., Umar, M., Munir, H., Sarfraz, Y., Umar, M. and Mehmood, A. (2016) Lithostratigraphy, Structure and Economic Geology of Abbottabad-Nathiagali-Kuldana-Murree Road Section, Abbottabad and Rawalpindi Districts, Khyber Pakhtunkhwa and Punjab Provinces, Pakistan. Abstract Volume, Earth Sciences Pakistan 2016, 15-17 July, Baragali Summer Campus, University of Peshawar, Pakistan. Journal of Himalayan Earth Sciences, 2016, 168.

[45] Malkani, M.S. and Mahmood, Z. (2016) Revised Stratigraphy of Uppermost Indus 
(Khyber-Hazara-Kashmir) Basin, Pakistan. Abstract Volume, Earth Sciences Pakis$\tan$ 2016, 15-17 July, Baragali Summer Campus, University of Peshawar, Pakistan. Journal of Himalayan Earth Sciences, 2016, 105.

[46] Malkani, M.S. (2014) Revised Stratigraphy of Balochistan Basin, Pakistan. In, Abstract Volume, Earth Sciences Pakistan 2014, August 29-31, Baragali Summer Campus, University of Peshawar, Pakistan. Journal of Himalayan Earth Sciences, 2014, 59-60.

[47] Malkani, M.S. (2000) Preliminary Report on Gypsum Deposits of Sulaiman Range, Pak. Geological Survey of Pakistan, Information Release, No. 706, 1-11.

[48] Malkani, M.S. (2018) Cement Resources and Gypsum Deposits of Pakistan: Urgent Installation of Cement Industries in Daman of Sulaiman Range. In, 5th International Conference on "Earth Sciences Pakistan 2018" August 11-13, 2018, Baragali Campus, University of Peshawar, Pakistan. Journal of Himalayan Earth Sciences, 2018, 180.

[49] Malkani, M.S. (2002) First Note on the Occurrence of Fluorite in Mula Area, Khuzdar District, Balochistan, Pakistan. Geological Survey of Pakistan, Information Release, No. 766, 1-11.

[50] Malkani, M.S. (2004) Discovery of Fluorite Deposits from Mula-Zahri Range, Khuzdar District, Balochistan, Pakistan. Fifth Pakistan Geological Congress, Abstract Volume, Islamabad, 14-15 April, 2004, 20-22.

[51] Malkani, M.S. (2012) Discovery of Fluorite Deposits from Loralai District, Balochistan, Pakistan. In, Abstract Volume, Earth Sciences Pakistan 2012, June 23-24, Baragali Summer Campus, University of Peshawar, Pakistan. Journal of Himalayan Earth Sciences, 45, 69.

[52] Malkani, M.S. (2015) Mesozoic Tectonics and Sedimentary Mineral Resources of Pakistan. 12 th Symposium on Mesozoic Terrestrial Ecosystems (MTE 12), and 3rd Symposium of IGCP 608 Cretaceous Ecosystem of Asia and Pacific, 15-20 August 2015, Abstract Volume, 261-266.

[53] Malkani, M.S., Alyani, M.I. and Khosa, M.H. (2016) New Fluorite and Celestite Deposits from Pakistan: Tectonic and Sedimentary Mineral Resources of Indus Basin (Pakistan)-An Overview. Lasbela University Journal of Science and Technolo$g y, 5,27-33$.

[54] Malkani, M.S. and Mahmood, Z. (2017) Fluorite from Loralai-Mekhtar and Celestite from Barkhan, Dera Bugti, Kohlu, Loralai and Musakhel Districts (Sulaiman Foldbelt) and Karkh Area of Khuzdar District (Kirthar Range): A Glimpse on Tectonic and Sedimentary Mineral Resources of Indus Basin (Pakistan). Geological Survey of Pakistan, Information Release, No. 981, 1-16.

[55] Malkani, M.S. (2012) Discovery of Celestite Deposits in the Sulaiman (Middle Indus) Basin, Balochistan, Pakistan. Abstract Volume and Program, Earth Sciences Pakistan, Baragali Summer Campus, University of Peshawar, June 23-24, Pakistan. Journal of Himalayan Earth Sciences, 45, 68-69.

[56] Malkani, M.S. (2004) Coal Resources of Chamalang, Bahney Wali and Nosham-Bahlol Areas of Kohlu, Barkhan, Loralai and Musa Khel Districts, Balochistan, Pakistan. National Conference on Economic and Environmental Sustainability of Mineral Resources of Pakistan, Baragali, Abstract Volume, 44-45.

[57] Malkani, M.S. (2012) A Review of Coal and Water Resources of Pakistan. Journal of Science, Technology and Development, 31, 202-218.

[58] Malkani, M.S., Alyani, M.I., Khosa, M.H. Buzdar, F.S. and Zahid, M.A. (2016) Coal 
Resources of Pakistan: New Coalfileds. Lasbela University Journal of Science and Technology, 5, 7-22.

[59] Malkani, M.S. (2016) New Coalfields of Balochistan, Khyber Pakhtunkhwa, FATA and Azad Kashmir. Abstract Volume, Qazi, M.S., Ali, W. eds., International Conference on Sustainable Utilization of Natural Resources, October 03, National Centre of Excellence in Geology, University of Peshawar, Peshawar, Pakistan. Journal of Himalayan Earth Sciences, 2016, 53-54.

[60] Malkani, M.S. and Mahmood, Z. (2017) Coal Resources of Pakistan: Entry of New Coalfields. Geological Survey of Pakistan, Information Release, No. 980, 1-28.

[61] Malkani, M.S. (2018) Chamalang-Lunda-Nosham Coalfields of Balochistan, Pakistan: Foresight Strategy and Policy. In, 5th International Conference on "Earth Sciences Pakistan 2018” August 11-13, 2018, Baragali Campus, University of Peshawar, Pakistan. Journal of Himalayan Earth Sciences, 2018, 26.

[62] Malkani, M.S. and Dhanotr, M.S.I. (2018) Kingri and Toi Nala (Ghoze Ghar-Savi Ragha) Coalfields of Musakhel District, Balochistan, Pakistan: Foresight Strategy. In, 5th International Conference on "Earth Sciences Pakistan 2018" August 11-13, 2018, Baragali Campus, University of Peshawar, Pakistan. Journal of Himalayan Earth Sciences, 2018, 21.

[63] Malkani, M.S. (2013) Coal and Petroleum Resources of Khyber Pakhtunkhwa and FATA (Pakistan) - An Overview. Abstract, Sustainable Utilization of Natural Resources of the Khyber Pakhtunkhwa and FATA. Abstract Volume, Sustainable Utilization of Natural Resources of the Khyber Pakhtunkhwa, February 11, Peshawar, Pakistan. Journal of Himalayan Earth Sciences, 2013, 27-29.

[64] Malkani, M.S. and Mahmood, Z. (2016) Coal Resources of Pakistan: New Coalfields of Balochistan, Khyber Pakhtunkhwa and Azad Kashmir. Abstract Volume, Earth Sciences Pakistan 2016, 15-17 July, Baragali Summer Campus, University of Peshawar, Pakistan. Journal of Himalayan Earth Sciences, 2016, 102.

[65] Malkani, M.S. and Shah, M.R. (2016) Chamalang Coal Resources and Their Depositional Environments, Balochistan, Pakistan. Geological Survey of Pakistan, Information Release, No. 969, 1-13.

[66] Malkani, M.S. and Shah, M.R. (2014) Chamalang Coal Resources and Their Depositional Environments, Balochistan, Pakistan. Journal of Himalayan Earth Sciences, 47, 61-72.

[67] Ahmad, W., Gauhar, S.H. and Siddiqui, R.A. (1986) Coal Resources of Pakistan. Geological Survey of Pakistan, Record, Vol. 73, 1-55.

[68] Ghaznavi, M.I. (2002) An Overview of Coal Resources of Pakistan. Geological Survey of Pakistan, Pre Publication Issue 114, 1-167.

[69] Malkani, M.S. and Mahmood, Z. (2016) Clay (Ceramic) Mineral Resources of Pakistan: Recent Advances in Discoveries. In, Earth Sciences Pakistan 2016, 15-17 July, Baragali Summer Campus, University of Peshawar, Pakistan. Journal of Himalayan Earth Sciences, 2016, 101.

[70] Malkani, M.S. and Tariq, M. (2000) Barite Mineralization in Mekhtar Area, Loralai District, Balochistan, Pakistan. Geological Survey of Pakistan, Information Release, No. 672, 1-9.

[71] Malkani, M.S. and Tariq, M. (2004) Discovery of Barite Deposits from the Mekhtar Area, Loralai District, Balochistan, Pakistan. National Conference on Economic and Environmental Sustainability of Mineral Resources of Pakistan, Baragali, Abstract Volume, 48 . 
[72] Malkani, M.S. (2010) New Pakisaurus (Pakisauridae, Titanosauria, Sauropoda) Remains and Cretaceous Tertiary (K-T) Boundary from Pakistan. Sindh University Research Journal (Science Series), 42, 39-64.

[73] Malkani, M.S., Qazi, S., Mahmood, Z., Khosa, M.H., Shah, M.R., Pasha, A.R. and Alyani, M.I. (2016) Agromineral Resources of Pakistan: An Urgent Need for Further Sustainable Development. Abstract Volume, Qazi, M.S., Ali, W. eds. International Conference on Sustainable Utilization of Natural Resources, October 03, National Centre of Excellence in Geology, University of Peshawar, Peshawar, Pakistan. Journal of Himalayan Earth Sciences, 2016, 51-52.

[74] Mahmood, Z. and Malkani, M.S. (2017) Good Quality Marble Deposits from Nausehri-Jhugian Area of Muzaffarabad Region, Neelam Valley, Azad Kashmir (Pakis$\tan )$. Geological Survey of Pakistan, Information Release, No. 978, 1-11.

[75] Malkani, M.S. and Mahmood, Z. (2017) Micaceous Hematite Deposit from Bala Pir-Bela Noor Shah area of Muzaffarabad District, Azad Kashmir (Pakistan). Geological Survey of Pakistan, Information Release, No. 977, 1-10.

[76] Malkani, M.S., Qazi, S., Khosa, M.H., Shah, M.R., Zafar, T. and Arif, J. (2018) Iron, Laterite, Bauxite and Ochre Deposits of Pakistan: Emphasis on Feasible Dilband and Low Grade Fort Munro Ironstones. In, 5th International Conference on "Earth Sciences Pakistan 2018” August 11-13, 2018, Baragali Campus, University of Peshawar, Pakistan. Journal of Himalayan Earth Sciences, 2016, 178-179.

[77] Malkani, M.S., Qazi, S., Khosa, M.H., Shah, M.R., Zafar, T. and Arif, J. (2018) Industrial Mineral Deposits of Pakistan: Significant for Sustainable Development of Pakistan. In, 5th International Conference on "Earth Sciences Pakistan 2018" August 11-13, 2018, Baragali Campus, University of Peshawar, Pakistan. Journal of Himalayan Earth Sciences, 2018, 175-176.

[78] Malkani, M.S., Qazi, S., Shah, M.R. and Zafar, T. (2018) Sandstone Type Uranium Resources of Pakistan: Encouraging Huge Strata. In, 5th International Conference on "Earth Sciences Pakistan 2018” August 11-13, 2018, Baragali Campus, University of Peshawar, Pakistan. Journal of Himalayan Earth Sciences, 2018, 167.

[79] Malkani, M.S. and Haq, M. (1998) Discovery of Pegmatite and Associated Plug in Tor Ghundi, Shabozai Area, Loralai District, Balochistan, Pakistan. Geological Survey of Pakistan, Information Release, No. 668, 1-19.

[80] Bilqees, R. and Shah, M.T. (2007) Industrial Applications of Limestone Deposits of Kohat, KPK: Aresearch towards the Sustainability of Deposits. Pakistan Journal of Scientific and Industrial Research, 50, 293-298.

[81] Oates, J.A.H. (1998) Lime and Limestone, Chemistry and Technology, Production and Uses. Wiley-VCH, Weinheim. https://doi.org/10.1002/9783527612024

[82] Gauher, S.H. (1966) Cement Resources of Pakistan. Geological Survey of Pakistan, Pre Publication Issue 11, 1-44.

[83] Alam, G.S. and Khan, A.L. (1982) Gypsum and Anhydrite Deposits in Salt Range. Geological Survey of Pakistan, Record, 59.

[84] Alizai, A.H., Mir, M.A. and Chandio, A.H. (2000) Gypsum Deposits of Johi, Khairpur Nathan Shah Areas, Dadu District. Geological Survey of Pakistan, Information Release, No. 731, 1-13.

[85] Hussain, A. and Karim, T. (1993) Mineral Map of NWFP. Geological Survey of Pakistan, Special Publication.

[86] Sheikh, G.M. (1972) Evaluation of Gypsum Resources in Spintangi Area, Sibi Distt, Balochistan, Pakistan. Geological Survey of Pakistan, Information Release, No. 52. 
[87] Stanin, S.A. and Hasan, M.S. (1966) Reconnaissance for Phosphate in West Pakistan. Geological Survey of Pakistan, Information Release, No. 32, 1-17.

[88] Hassan, M.T. and Ghaznavi, M.I. (1980) Phosphate Deposits of Hazara Division, NWFP. Geological Survey of Pakistan, Record, No. 50, 1-24.

[89] Waliullah, Karim, T. and Ashraf, M. (2012) Preliminary Report on the Newly Discovered Phosphate Deposits of Soban Gali, Paswal Mian and Banseri Areas, District Abbottabad, Khyber Pakhtunkhwa. Abstract Volume, Earth Sciences Pakistan, Baragali Summer Campus, University of Peshawar, June 23-24, Pakistan. Journal of Himalayan Earth Sciences, 45, 106.

[90] Qureshi, A.A., Khattak, N., Karim, T. and Waheed, S. (2000) Geology and Economic Significance of the Loe-Shilman Carbonatite Complex, Khyber Agency, Pakistan. Geologica, 5, 133-144.

[91] Griffiths, J.B. (1987) Pakistan Mineral Potential: Prince or Pauper. Industrial Minerals, 238, 220-243.

[92] Asrarullah (1962) Rock Salt Occurrences of Pakistan. CENTO Sym. on Industrial Rocks and Minerals, Lahore, 303-313.

[93] Rashid, M.A., Hussain, M., Master, J.M. and Meissner, C.R. (1965) Mineral Deposits of Eastern Kohat. Geological Survey of Pakistan, Record, Vol. 13, pt. 2, 1-16.

[94] Khan, A. (2012) Overview of Mineral Sector of Pakistan. Abstract Volume, Earth Sciences Pakistan, Baragali Summer Campus, University of Peshawar, June 23-24, Pakistan. Journal of Himalayan Earth Sciences, 45, 53-54.

[95] Asrarullah, H.A. (1963) Marble Deposits of West Pakistan. Symposium on Industrial Rocks and Minerals, Lahore, 179-188.

[96] Asrarullah, H.A. (1985) Marble Deposits of North Western Frontier Province, Pakistan. Geological Survey of Pakistan, Information Release, No. 128, 1-23.

[97] Dilpazir, H. and Bilqees, R. (2012) Evaluation of Slates from Attock-Cherat Range for Use as Structural Light Weight Concrete Aggregate. Abstract Volume, Earth Sciences Pakistan, Baragali Summer Campus, University of Peshawar, June 23-24, Pakistan. Journal of Himalayan Earth Sciences, 45, 27-28.

[98] Khan, B. (2004) Marble and Granite Sector of Pakistan. National Conference on Economic and Environmental Sustainability of Mineral Resources of Pakistan, Baragali, Abstract Volume, 35-36.

[99] Gingerich, P.D., Haq, M., Zalmout, I.S., Khan, I.H. and Malkani, M.S. (2001) Origin of Whales from Early Artiodactyls: Hands and Feet of Eocene Protocetidae from Pakistan. Science, 293, 2239-2242. https://doi.org/10.1126/science.1063902

[100] Malkani, M.S., Dhanotr, M.S.I., Latif, A. and Saeed, H.M. (2013) New Remains of Basilosauridae-The Giant Basal Whale, and Baluchithere-The Giant Rhinoceros Discovered from Balochistan Province (Pakistan). Sindh University Research Journal (Science Series), 45, 177-188.

[101] Malkani, M.S. (2019) Recently Discovered Basilosaurid, Baluchithere Rhinoceros, Horses, Sea Cow, Proboscidean, Eucrocodile, Pterosaurs, Plesiosaur, Fishes, Invertebrates and Wood Fossils, Tracks and Trackways of Dinosaurs from Pakistan; Comparison of Recognized Four Titanosaur Taxa of Indo-Pakistan with Madagascar. Open Journal of Geology, 9, 919-955. https://doi.org/10.4236/ojg.2019.912098

[102] Malkani, M.S. (2020) First Skull of Medium Sized Titanosaur from Indo-Pakistan Subcontinent Found from the Latest Maastrichtian Vitakri Formation of Pakistan; Associated Cranial and Postcranial Skeletons of Gspsaurus pakistani (Poripuchia, Stocky Titanosauria, Sauropoda) from Pakistan and India. Open Journal of Geolo- 
gy, 10, 448-489. https://doi.org/10.4236/ojg.2020.104020

[103] Malkani, M.S. (2020) First Snout with Complete Teeth Row of Titanosaur from Indo-Pakistan Subcontinent Found from the Latest Maastrichtian Vitakri Formation of Pakistan; Associated Cranial and Postcranial Skeletons of Saraikimasoom vitakri (Poripuchia, Stocky Titanosauria, Sauropoda) from Pakistan and Referred Fossils from India. Open Journal of Geology, 10, 368-407.

https://doi.org/10.4236/ojg.2020.104018

[104] Malkani, M.S. (2020) Pakisaurus balochistani (Poripuchia, Slender Titanosauria, Sauropoda) Associated Skeletons from the Latest Maastrichtian Vitakri Formation of Pakistan and Referred Fossils from India; Filling of Significant Missing Links of Isisaurus colberti (Poripuchia, Slender Titanosauria, Sauropoda) Found from $\mathrm{Pa}$ kistan. Open Journal of Geology, 10, 408-447. https://doi.org/10.4236/ojg.2020.104019

[105] Malkani, M.S. (2015) Dinosaurs, Mesoeucrocodiles, Pterosaurs, New Fauna and Flora from Pakistan. Geological Survey of Pakistan, Information Release, No. 823, $1-32$.

[106] Malkani, M.S. (2010) Osteoderms of Pakisauridae and Balochisauridae (Titanosauria, Sauropoda, Dinosauria) in Pakistan. Journal of Earth Science, 21, 198-203. https://doi.org/10.1007/s12583-010-0212-Z

[107] Malkani, M.S. (2009) New Balochisaurus (Balochisauridae, Titanosauria, Sauropoda) and Vitakridrinda (Theropoda) Remains from Pakistan. Sindh University Research Journal (Science Series), 41, 65-92.

[108] Malkani, M.S. (2008) Marisaurus (Balochisauridae, Titanosauria) Remains from the Latest Cretaceous of Pakistan. Sindh University Research Journal (Science Series), 40, 55-78.

[109] Malkani, M.S. (2008) First Articulated Atlas-Axis Complex of Titanosauria (Sauropoda, Dinosauria) Uncovered from the Latest Cretaceous Vitakri Member (Dinosaur Beds) of Upper Pab Formation, Kinwa Locality of Sulaiman Basin, Pakistan. Sindh University Research Journal (Science Series), 40, 55-70.

[110] Malkani, M.S. (2006) Biodiversity of Saurischian Dinosaurs from the Latest Cretaceous Park of Pakistan. Journal of Applied and Emerging Sciences, 1, 108-140.

[111] Malkani, M.S. (2006) Lithofacies and Lateral Extension of Latest Cretaceous Dinosaur Beds from Sulaiman Foldbelt, Pakistan. Sindh University Research Journal (Science Series), 38, 1-32.

[112] Malkani, M.S. (2003) First Jurassic Dinosaur Fossils Found from Kirthar Range, Khuzdar District, Balochistan, Pakistan. Geological Bulletin, University of Peshawar, 36, 73-83.

[113] Malkani, M.S. (2003) Discovery of Partial Skull and Dentary of Titanosauria (Sauropod Dinosaur) from the Late Cretaceous Pab Formation of Vitakri Area, Barkhan District, Balochistan, Pakistan. Geological Bulletin, University of Peshawar, 36, 65-71.

[114] Malkani, M.S. (2003) Pakistani Titanosauria; Are Armoured Dinosaurs? Geological Bulletin, University of Peshawar, 36, 85-91.

[115] Malkani, M.S. (2020) Theropods, Mesoeucrocodiles and Pterosaurs Found from the Latest Maastrichtian Vitakri Formation of Balochistan, Pakistan; Description with Large Photographs and Comparison with Coeval Taxa from Indo-Pakistan Subcontinent. Open Journal of Geology, 10, 510-551.

https://doi.org/10.4236/ojg.2020.105023 
[116] Malkani, M.S. (2006) First Rostrum of Carnivorous Vitakridrinda (Abelisaurids Theropod Dinosaur) Found from the Latest Cretaceous Dinosaur Beds (Vitakri) Member of Pab Formation, Alam Kali Kakor Locality of Vitakri Area, Barkhan District, Balochistan, Pakistan. Sindh University Research Journal (Science Series), 38, 5-24.

[117] Wilson, J.A., Malkani, M.S. and Gingerich, P.D. (2001) New Crocodyliform (Reptilia, Mesoeucrocodylia) Form the Upper Cretaceous Pab Formation of Vitakri, Balochistan (Pakistan). Contributions from the Museum of Paleontology, the University of Michigan, 30, 321-336.

[118] Malkani, M.S. (2007) Trackways Evidence of Sauropod Dinosaurs Confronted by a Theropod Found from Middle Jurassic Samana Suk Limestone of Pakistan. Sindh University Research Journal (Science Series), 39, 1-14.

[119] Ali, S.T. (1967) Gemstones in Pakistan. Geological Survey of Pakistan, Pre Publication Issue 63, 1-13.

[120] Gubelin, E.J. (1982) Gemstones of Pakistan: Emerald, Ruby and Spinel. Gems and Gemology, 18, 123-139. https://doi.org/10.5741/GEMS.18.3.123

[121] Kazmi, A.H. and O’Donoghue, M. (1990) Gemstones of Pakistan. Gemstone Corporation of Pakistan, Pakistan, $146 \mathrm{p}$.

[122] Khan, T. and Kausar, A.B. (2010) Gems and Gemology in Pakistan. Special Publication of Geological Survey of Pakistan, $231 \mathrm{p}$.

[123] Ali, S.T. (1951) Alluvial Gold in Chitral. Geological Survey of Pakistan.

[124] Ali, S.T. (1959) Mineral Deposits and Showings in the Northern Part of Pakistan. Geological Survey of Pakistan, Information Release, 2.

[125] Clavarino, J.G., Dawney, R.L. and Sweatman, T.R. (1995) Gold Exploration in Northern Areas, Status and Prospects. Proceedings of Intern. Round Table Conference (1994) and Foreign Investment in Exploration and Mining in Pakistan, Pakistan, 93-120.

[126] Khan, H. and Shah, M.T. (2004) Mineralogy of the Heavy Mineral Concentrates of Placers and Extraction of Placer Gold in the Bagrot Valley, Gilgit Agency, Northern Pakistan. National Conference on Economic and Environmental Sustainability of Mineral Resources of Pakistan, Baragali, Abstract Volume, 37.

[127] Miandad, S., Shah, M.T., Khan, S.D. and Ali, L. (2012) Preliminary Study of the Rocks of Bagrot Valley, Gilgit-Baltistan, Pakistan with Emphasis on Gold and Base Metals Mineralization. Abstract Volume and Program, Earth Sciences Pakistan, Baragali Summer Campus, University of Peshawar, June 23-24, Pakistan. Journal of Himalayan Earth Sciences, 45, 79-80.

[128] Rehman, A., Shah, M.T., Khan, S.D. and Ali, L. (2012) Preliminary Investigations of the Rocks of Shigari Bala Area, Skardu, Gilgit-Baltistan, Pakistan in the Perspective of Gold and Base Metal Mineralization. Abstract Volume and Program, Earth Sciences Pakistan, Baragali Summer Campus, University of Peshawar, June 23-24, Pakistan. Journal of Himalayan Earth Sciences, 45, 84-85.

[129] Sheikh, L., Shah, M.T., Khan, S.D. and Ali, L. (2012) Preliminary Study of the Rocks of Golo Das and Surrounding Areas, Gilgit-Baltistan, Pakistan in the Perspective of Gold and Base Metals Mineralization. Abstract Volume, Earth Sciences Pakistan, Baragali Summer Campus, University of Peshawar, June 23-24, Pakistan. Journal of Himalayan Earth Sciences, 45, 102-103.

[130] Leake, R.C., Fletcher, C.J.N., Haslam, H.W., Khan, B. and Shakiullah (1989) Origin and Tectonic Setting of Stratabound Tungsten Mineralization in Hindu Kush of Pa- 
kistan. Journal of the Geological Society of London, 146, 1003-1016. https://doi.org/10.1144/gsjgs.146.6.1003

[131] Khan, M.A. and Ahmad, W. (1966) Report on SDA Mineral Activities in NWFP, Sarhad Development Authority, Directorate of Minerals. 46 p.

[132] Hussain, T., Khan, M.S., Hussain, K. and Chaudhry, M.N. (2000) Stratabound Volcanic Hosted Gold, Silver and Sulphide Mineralization in Paleocene-Eocene Dir Volcanic Group, District Dir, Pakistan. Proc. of Economic Geology of Pakistan, Pakistan, 83-88.

[133] Miller, D.J., Louks, R.R. and Ashraf, M. (1991) Platinum Group Element Mineral. In Jijal Layered Ultramafic-Mafic Complex, Pakistan. Economic Geology, 86, 1093-1102. https://doi.org/10.2113/gsecongeo.86.5.1093

[134] Kazmi, A.H. (1995). Precious Stones of Pakistan. Proceeding of International Round Table Conference, on Foreign Investment in Exploration and Mining in Pakistan, 16-18 October 1994, 57-70.

[135] Khan, T. and Kausar, A.B. (1996) Peridot Occurrence with Ferromagnetic Mineral in Dunite of Sapat Ultramaphic, Naran-Kohistan. Conference in Paleomagnetic Studies of Himalaya-Karakoram and Surrounding Continents, Geological Survey of Pakistan, Islamabad, 130.

[136] Koivula, J.E., Kammerling, R.C. and Fritsch, E. (1994) Gem News. Gems and Gemology, 30, 271-280. https://doi.org/10.5741/GEMS.30.4.271

[137] Arbab, M.S.H. and Khan, R.N. (1973) Ruby Corundum in Timurgara, Dir. Geological Survey of Pakistan, Information Release, No. 56, 1-5.

[138] Okrush, M., Bunch, T.E. and Bann, H. (1976) Paragenesis and Petrogenesis of a Coroundum Bearing Marble at Hunza (Kashmir). Mineralium Deposita, 11, 278-297. https://doi.org/10.1007/BF00203079

[139] Gubelin, E.J., Graziani, G. and Kazmi, A.H. (1986) Pink Topaz of Pakistan. Gems and Gemology, 22, 140-151. https://doi.org/10.5741/GEMS.22.3.140

[140] Arbab, M.S.H. and Qureshi, I.H. (1972) Topaz in Ghundao Village, Katlang, Mardan. Geological Survey of Pakistan, Information Release, No. 50, 1-4.

[141] Khan, T. and Kausar, A.B. (2004) The Discovery of Rare Earth Bearing Gemstone (Bastnasite) in Pakistan. Fifth Pakistan Geological Congress, Islamabad, Abstract Volume, 86.

[142] Ahmad, M.I. (1954) A Short Note on the Occurrence of Fluorite Rock near Sherwan, Hazara District, Pakistan. Geological Survey of Pakistan, File No. 544 (54).

[143] Nagell, R.H. (1969) Sulphur, Fluorspar, Magnesite and Aluminous Chromite Deposits in West Pakistan. United States Geological Survey, pk Series No. 49, 1-33.

[144] Assistant Political Agent, Skardu (1956) A Letter to Geological Survey of Pakistan. Geological Survey of Pakistan File No. 351(1), 1-24.

[145] Kazmi, A.H. and Snee, L.W. (1989) Emerald of Pakistan: Geology, Gemology and Genesis. Van Nostrand Reinhold, New York, 269 p.

[146] Alam, G.S. and Cheema, M.R. (1974) Hunza Spinal (Ruby Spinal) Deposits, Hunza State, Gilgit, Pakistan. Geological Survey of Pakistan, Information Release, 77.

[147] Kazmi, A.H., Peters, J.J. and Obodda, H.P. (1985) Gem Pegmatites of the Shingus-Dusso Area, Gilgit, Pakistan. The Mining Record, 16, 393-411.

[148] Agheem, M.H. and Shah, M.T. (2004) Gems and Gem Bearing Pegmatites of the Shigar Valley, Skardu, Northern Pakistan. Conference on Economic and Environmental Sustainability of Mineral Resources of Pakistan, Baragali, Abstracts Vol- 
nume, 1 .

[149] Islam, N.U., Hussain, S.A., Abbas, S.Q. and Ashraf, M. (2010) Mineral Statistics of Pakistan. Geological Survey of Pakistan, Special Issue.

[150] Malik, R.H. (1995) Geology and Resource Potential of Azad Kashmir Ruby Deposits. Proc. Round Table Conference on Foreign Investment in Exploration and Mining in Pakistan, Pakistan, 153-172.

[151] Baig, M.S. and Perveez, S. (2004) Structure and Ruby Mineralization of Khandigali-Nangimali Area, Neelam Valley, Azad Kashmir, Northwestern Himalaya, Pakistan. Fifth Pakistan Geological Congress, Islamabad, Abstract Volume, 29-31.

[152] Naeem, A., Mahmood, K. and Kakar, M.I. (2014) A Study of the Gemstones from the Muslimbagh Ophiolite Complex, Balochistan, Pakistan. In, Abstract Volume, Earth Sciences Pakistan 2014, August 29-31, Baragali Summer Campus, University of Peshawar, Pakistan. Journal of Himalayan Earth Sciences, 2014, 63-64.

[153] Ahmad, M.U. (1986) Dasht-e-Kain Porphry Copper in Context of Metallogeny of Chagai Calc-Alkaline Volcano Intrusive Complex Chagai District, Pakistan. PhD Thesis.

[154] Bakar, M.A. (1962) Fluorspar Deposits in the Northern Part of Koh-i-Maran Range, Kalat Division, West Pakistan. Geological Survey of Pakistan, Record, Vol. 9(2), 1-7.

[155] Mohsin, S.I. and Sarwar, G. (1974) Geology of Dilband Fluorite Deposits. Geonews, 4, 24-30.

[156] Abbas, S.G., Sultan, M. and Bahadur, S. (1980) Geology and Economic Potential for Fluorite in Dilband, Maran and Pad Maran Areas, District Kalat, Balochistan, Pakistan. Geological Survey of Pakistan, Unpublished Report.

[157] Shah, S.M.I. (1973) Occurences of Gold in the Kirana Group, Sargodha (Punjab), Pakistan. Geological Survey of Pakistan, Information Release, No. 68, 1-14.

[158] Ahmad, W. (Undated) Mica and Beryl Occurrences in the Talash Region, Dir State. Geological Survey of Pakistan, Unpublished.

[159] Ahmad, W. (1966) A Short Note on the Emerald Deposits, Nawe Dand, Mohmand Agency, Peshawar. Geological Survey of Pakistan, Pre Publication Issue, No. 29, 1-4.

[160] Butler, B.C.M. (1963) An Occurrence of Nephrite Jade in West Pakistan. Geological Survey of Pakistan, Record No. 7, pt. 2, 1-146. 